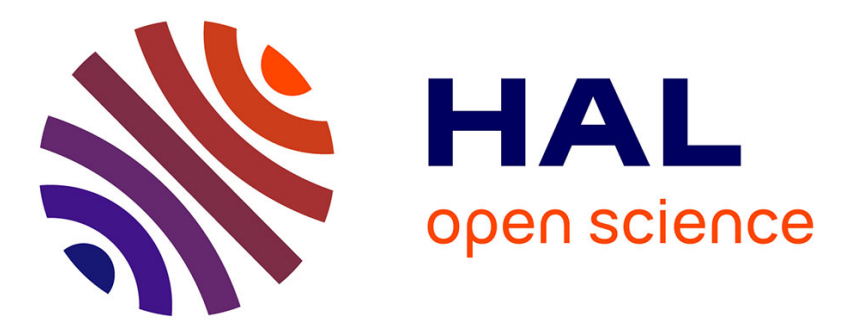

\title{
Temporal variations of the segmentation of slow to intermediate spreading mid-ocean ridges 1 . Synoptic observations based on satellite altimetry data
}

Anne Briais, Michel Rabinowicz

\section{- To cite this version:}

Anne Briais, Michel Rabinowicz. Temporal variations of the segmentation of slow to intermediate spreading mid-ocean ridges 1. Synoptic observations based on satellite altimetry data. Journal of Geophysical Research: Solid Earth, 2002, pp.VOL. 107, NO. B5, 2098. 10.1029/2001JB000533 . hal-00552201

\author{
HAL Id: hal-00552201 \\ https://hal.science/hal-00552201
}

Submitted on 5 Jan 2011

HAL is a multi-disciplinary open access archive for the deposit and dissemination of scientific research documents, whether they are published or not. The documents may come from teaching and research institutions in France or abroad, or from public or private research centers.
L'archive ouverte pluridisciplinaire HAL, est destinée au dépôt et à la diffusion de documents scientifiques de niveau recherche, publiés ou non, émanant des établissements d'enseignement et de recherche français ou étrangers, des laboratoires publics ou privés. 


\title{
Temporal variations of the segmentation of slow to intermediate spreading mid-ocean ridges \\ 1. Synoptic observations based on satellite altimetry data
}

\author{
Anne Briais \\ Laboratoire d'Etudes en Géophysique et Océanographie Spatiales, CNRS, UMR 5566, Observatoire Midi-Pyrénées, \\ Toulouse, France
}

Michel Rabinowicz

Laboratoire de Dynamique Terrestre et Planétaire, UMR 5562, Observatoire Midi-Pyrénées, Toulouse, France

Received 30 May 2000; revised 15 June 2001; accepted 3 July 2001; published 25 May 2002.

[1] The high-resolution geoid and gravity maps derived from ERS-1 and Geosat satellite geodetic missions reveal a set of small-scale lineations on the flanks of slow to intermediate spreading midocean ridges. Assuming that these lineations reflect the variations in crustal structure induced by mid-ocean ridge axial discontinuities, we use them to investigate how the discontinuities, and the segments they bound, appear, migrate, and disappear. We provide a synoptic description of the main characteristics of the crustal structure variations, as well as their evolution in time, over the flanks of the Mid-Atlantic, Indian, and Pacific-Antarctic Ridges. The second-order segment length does not appear to vary with the spreading rate for the slow to intermediate spreading ridges investigated here. The amplitude of the gravity signal associated with off-axis discontinuity traces increases with the obliquity of the ridge to spreading and decreases with spreading rate and with the proximity of a ridge section to a hot spot. The patterns of the gravity lineations appear to be very homogeneous over 500 - to 1000 -km-large corridors bounded by large fracture zones. Far from hot spots, corridors are characterized either by segments bounded by discontinuities migrating back and forth along the axis, implying a lifetime of 10-30 Myr for the segments, or by segments and discontinuities very stable in space and time, surviving for 40-50 Myr. Closer to hot spots, the segmentation is affected in two ways. First, segments tend to migrate along axis away from hot spots, or toward cold spots. Second, asymmetric spreading tends to keep sections of ridges closer to hot spots than normal spreading would. These observations support the hypothesis that ridge segmentation and its evolution are controlled by mantle dynamics. Our analysis provides observational constraints for further models of crustal production along ridges, which are presented in the companion paper by Rabinowicz and Briais [2002]. INDEX TERMS: 3010 Marine Geology and Geophysics: Gravity; 3035 Marine Geology and Geophysics: Midocean ridge processes; 8120 Tectonophysics: Dynamics of lithosphere and mantle — general; 8121 Tectonophysics: Dynamics, convection currents and mantle plumes; KEYWORDS: Mid-ocean ridge, mantle convection, ridge segmentation, gravity lineations, oceanic crust, mantle melting

\section{Introduction}

[2] A major improvement in our understanding of accretionary processes along mid-ocean ridges was brought by multibeam bathymetry surveys which revealed that these processes are segmented into accretionary cells, spaced $\sim 20-150 \mathrm{~km}$ along the axis [Crane, 1985; Schouten et al., 1985; Macdonald, 1986; Macdonald et al., 1991; Sempéré et al., 1993]. On ridges with an axial valley, usually slow spreading ridges, the segmentation is marked by large along-axis variations in the structure of the oceanic lithosphere. Combined gravity and bathymetric studies suggest that oceanic crust generated in the center of the segments is up to $\sim 6 \mathrm{~km}$ thicker than near the discontinuities [Kuo and Forsyth, 1988; Lin et al., 1990]. This hypothesis was confirmed by seismic studies [Cormier et al., 1984; Tolstoy et al., 1993; Wolfe et al., 1995; Barclay et al., 1998] and by the recovery of peridotites near discontinuities [e.g., Lagabrielle et al., 1998]. These structural variations are most often, but not necessarily, associated with axial offsets. Ridges with an axial rise do not display such large structural variations associated with the second-order segmentation. Off-axis surveys have shown that discontinuity offsets vary with time, sometimes including a change in the sense of the offset [Carbotte et al., 1991; Grindlay et al., 1991; Sloan and Patriat, 1992; Sempéré et al., 1995; Tucholke et al., 1997]. The traces of the small-offset discontinuities show that both the accretionary cells and the discontinuities tend to migrate along the ridge axis, resulting in net migration, lengthening, or shortening of ridge segments [Schouten et al., 1987; Grindlay et al., 1991; Macdonald et al., 1991; Sloan and Patriat, 1992; Rommevaux et al., 1994; Gente et al., 1995; Sempéré et al., 1995; Tucholke et al., 1997].

[3] The factors controlling the origin and the dynamics of the axial segmentation are still largely unknown. The general shape of a mid-ocean ridge is often attributed to the initial breakup of the continents, and the variations of its geometry are inferred to result from changes in the spreading direction, a mechanism valid for sections of the northern Atlantic or Indian Ridges. Plate kinematic changes, however, explain neither the crenulated geometry of the 
southern Mid-Atlantic Ridge (MAR) or of the Southeast Indian Ridge (SEIR) in the Australia-Antarctic Discordance (AAD) region, which display offsets in either sense, nor the existence of large, along-axis crustal structure variations in the absence of axial offsets. Tucholke et al. [1997] provide a good summary of the debate between a "magmatic" hypothesis and a "tectonic" hypothesis to explain the origin and evolution of the axial segmentation. According to the magmatic hypothesis the segmentation is controlled by the focusing of melt under segment centers, resulting either from melt diapirism [Whitehead et al., 1985] or from zones of focused mantle upwelling [Scott and Stevenson, 1989; Parmentier and Phipps Morgan, 1990; Jha et al., 1994]. According to the tectonic hypothesis, lithospheric faulting is responsible for the segmentation [Mutter and Karson, 1992], and mantle upwelling is passive and controlled by axial geometry and discontinuity offsets [Phipps Morgan and Forsyth, 1988]. Tucholke et al. [1997] rule out the tectonic hypothesis by showing how a ridge axis discontinuity is maintained at the axis despite a change in its sense of offset. Here we want to go further and present a systematic analysis of the evolution of the segmentation in various thermal and kinematic conditions to evaluate the factors responsible for the characteristics of the axial segmentation and its evolution in time.

[4] One of the most spectacular features in the high-resolution geoid and gravity maps derived from ERS-1 and Geosat satellite geodetic missions is the set of small-scale lineations on the flanks of slow to intermediate spreading mid-ocean ridges created by the off-axis traces of axial discontinuities [Phipps Morgan and Parmentier, 1995; Cazenave et al., 1996; Sandwell and Smith, 1997; Hwang et al., 1998]. In this paper we take advantage of this complete coverage of the ocean basins by satellite altimetry data to investigate how the discontinuities, and the segments they bound, appear, migrate, and disappear. We provide a synoptic description of the main characteristics of the crustal structure variations, as well as their evolution in time, over various, large ocean basins to provide observational constraints for further models of crustal production along ridges. We present a comprehensive analysis of the geographical distribution, obliquity, length, and amplitude of the lineations observed in the satellite-derived marine gravity maps. We analyze these characteristics in terms of the interaction between the axial segmentation and the regional tectonic and thermal conditions reflecting the large-scale mantle convective flow. The main conclusions of this data analysis are then used as major constraints in numerical models of generation and evolution of the segmentation of mid-ocean ridges, which are presented in the companion paper by Rabinowicz and Briais [2002].

\section{Data and Methodology}

[5] We use the vertical gravity gradient and the marine free-air gravity grids derived from the geodetic phases of the ERS-1 and Geosat missions [Sandwell and Smith, 1997; Hwang et al., 1998; W. H. F. Smith, written communication, 1999] to map the traces of the ridge axis discontinuities (RADs) on the flanks of mid-ocean ridges (Figure 1). Satellite altimetry data have been used for a long time to follow fracture zones (FZs), which are marked by a characteristic step in the height of the geoid and to analyze the geoid disruption across them. The purpose of these analyses was to constrain models for the thermal evolution of the oceanic lithosphere [e.g., Cazenave et al., 1982] or kinematic models considering FZs as small circles about the pole of rotation of the plates [e.g., Cande et al., 1988; Shaw and Cande, 1990]. The signature of large-offset FZs in the geoid or the gravity anomalies is attributed to the difference in lithospheric thickness across the FZ, the flexure of the lithosphere resulting from differential cooling, and the crustal structure near the FZ [e.g., Cazenave et al., 1982; Sandwell, 1984]. For small-offset RADs and their traces, however, the gravimetric signature is mostly due to crustal structure variations along axis, which induce significant depth variations [e.g., Kuo and Forsyth, 1988; Lin et al., 1990; Müller and Roest, 1992; Phipps Morgan and Parmentier, 1995] and which are also recorded in the off-axis lithosphere [Neumann and Forsyth, 1993; Michael et al., 1994; Rommevaux et al., 1994; Pariso et al., 1995; Gente et al., 1995; Maia and Gente, 1998]. The main difference between the traces of transform faults and those of the nontransform RADs is that the latter often migrate along-axis, resulting in off-axis traces which do not follow small circles of the plate rotation.

[6] We map the traces of RADs over most oceanic ridge flanks, taking into account the along-axis migration of many of them. We consider that the free-air gravity minima at wavelengths of $20-100 \mathrm{~km}$ in directions within $60^{\circ}$ of the the flow lines of the plate movements depict the traces of RADs. Most of the digitized features have a conjugate feature on the other ridge flank, confirming their generation at the ridge axis. We do not consider the structures related to major events in the kinematic histories of the oceanic basins or the seamount chains related to hot spots, which can also generate short-wavelength gravity lineations. We produced a digitized set of the traces of the transform faults and the nontransform discontinuities by manually following these minima on gravity maps. The digitization was based on maps of the gradient of the marine gravity in directions perpendicular to the flow lines and maps of the vertical gradient of the gravity field. In regions surveyed by cruises we obtain a good superposition of the digitized lineations with the bathymetric lows that mark the traces of the discontinuities. Because the combined altimetry data permit mapping of oceanic features with a resolution as fine as $20 \mathrm{~km}$ [Marks, 1996], we can extrapolate the observations made from shipboard off-axis investigations to ocean basins and therefore analyze the evolution of the small-scale segmentation over $>100$ Myr. One of the objectives of the study is to compare the evolution of the segmentation with the kinematic parameters. Consequently, we avoided the areas where plate kinematics is too complex, like near triple junctions, such as the equatorial Atlantic, the Bouvet, or the Azores areas. We compare the distribution of the gravity lineations, inferred to result from the segmentation of the ridge axis, with the spreading rate and asymmetry (R. D. Müller, written communication, 1999). In our analysis of the evolution of the segmentation the age of the lineations is deduced from the global age grid of Müller et al. [1997].

\section{Analysis of the Segmentation}

\subsection{Characteristics of the Gravity Lineations}

3.1.1. Global distribution of the gravity signature of the axial segmentation. [7] The satellite gravity maps reveal that the small-scale gravity lineations representing the traces of axial segmentation are not ubiquitous [Phipps Morgan and Parmentier, 1995]. These lineations create "crenulations" [Phipps Morgan and Parmentier, 1995] or "roughness" [Small and Sandwell, 1992; Sahabi et al., 1996] on the seafloor as observed on the gravity maps. They are observed only in the young parts of the Atlantic and Indian Oceans and on the flanks of the southern PacificAntarctic Ridge (Figures 2-7). They are missing in the northern and central Pacific and in the oldest lithosphere in the South Atlantic and the Indian Oceans, where only large transform faults leave significant traces in the gravity maps.

[8] In the central Atlantic between $15^{\circ} \mathrm{N}$ and $38^{\circ} \mathrm{N}$ (Azores triple junction and hot spot), gravity lineations associated with RAD traces are observed over crust between $\sim 120$ and $100 \mathrm{Ma}$ and then for ages younger than $\sim 70 \mathrm{Ma}$ (Figure 2 ). Very few lineations are observed on the flanks of the MAR between $38^{\circ} \mathrm{N}$ and $47^{\circ} \mathrm{N}$. The lineations between $48^{\circ} \mathrm{N}$ and $53^{\circ} \mathrm{N}$ (Charlie-Gibbs Fracture Zone) are younger than $\sim 50 \mathrm{Ma}$. On the flanks of the Reykjanes Ridge, lineations subparallel to spreading appear near $35 \mathrm{Ma}$ and disappear gradually after $30 \mathrm{Ma}$, first in the north, then in the south. They are 

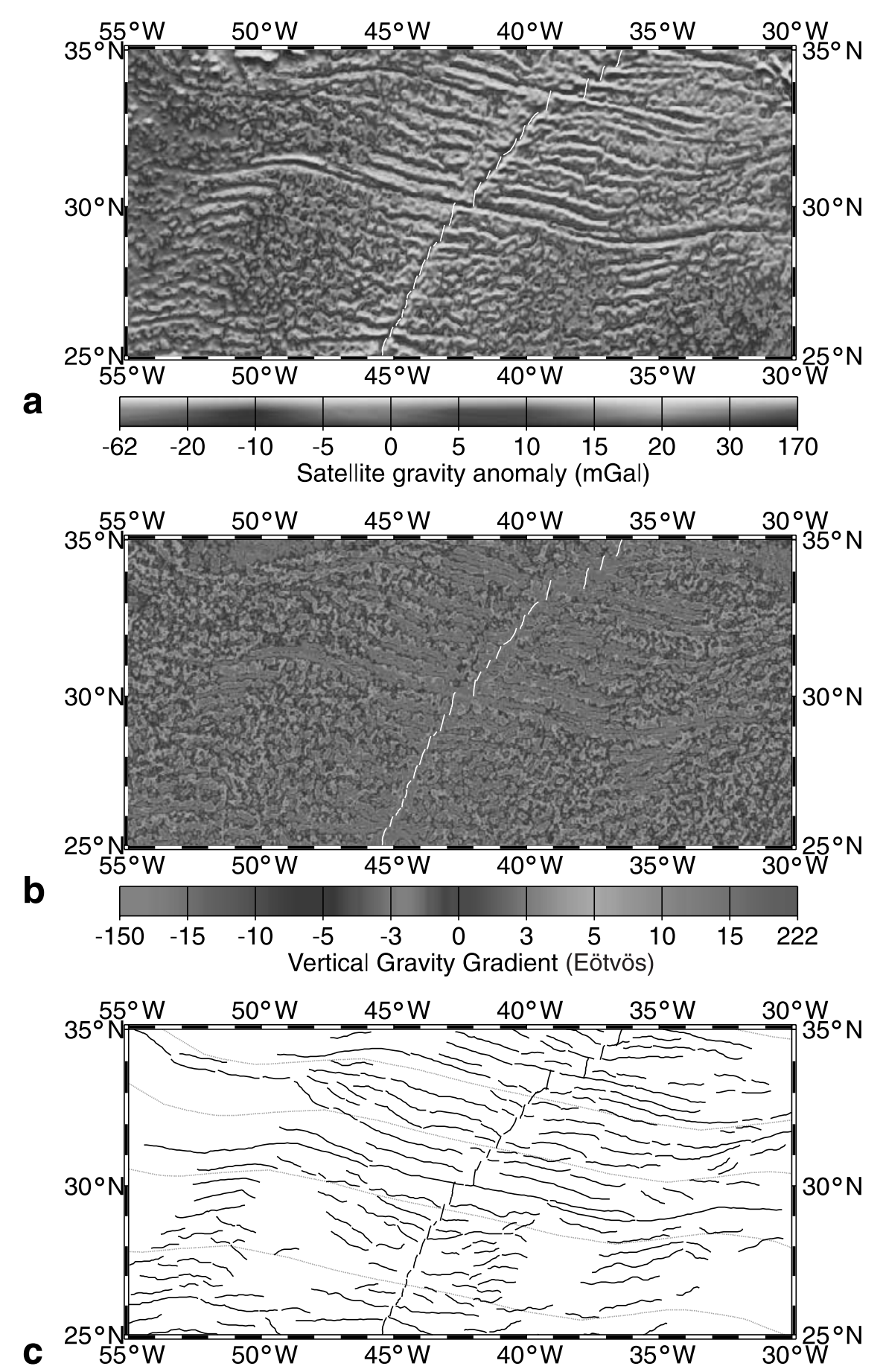

Figure 1. (a) Shaded relief map of the free-air gravity anomalies in the central Atlantic [Sandwell and Smith, 1997]. (b) Vertical gravity gradient in the same area as Figure 1a (W. H. F. Smith, written communication, 1999) (c) Discontinuity traces identified from Figures $1 \mathrm{a}$ and $1 \mathrm{~b}$ shown as thin solid lines. Thick lines are mid-ocean ridge axis. Dotted lines are flow lines drawn using Müller et al.'s [1997] finite poles of rotation. See color version of this figure at back of this issue.

then replaced by V-shaped lineations very oblique to the spreading direction [e.g., Vogt, 1971; White et al., 1995].

[9] To first order, the traces of RADs appear on the flanks of the southern Mid-Atlantic Ridge (SMAR) near 70 Ma between 0 and $30^{\circ} \mathrm{S}$ and near $40 \mathrm{Ma}$ between $34^{\circ} \mathrm{S}$ and $48^{\circ} \mathrm{S}$, and only a few discontinuity traces are observed in the southernmost section, between $48^{\circ} \mathrm{S}$ (Agulhas transform fault (TF)) and $64^{\circ} \mathrm{S}$ (Bouvet Triple Junction, Figure 3). This increase in the number of traces was interpreted by Cande et al. [1988] to reflect an increase in the number of fracture zones, since most of the traces observed in the satellite altimetry profiles are associated with an offset of the magnetic isochrons. Cande et al. [1988, p. 13,481] also noticed that the "fracture zone proliferation" corresponds to a period of relatively slow spreading of the SMAR between Chrons C30 and $\mathrm{C} 20(67-45 \mathrm{Ma})$, as well as to an "increase in the amplitude of the geoid anomalies over fracture zones." 


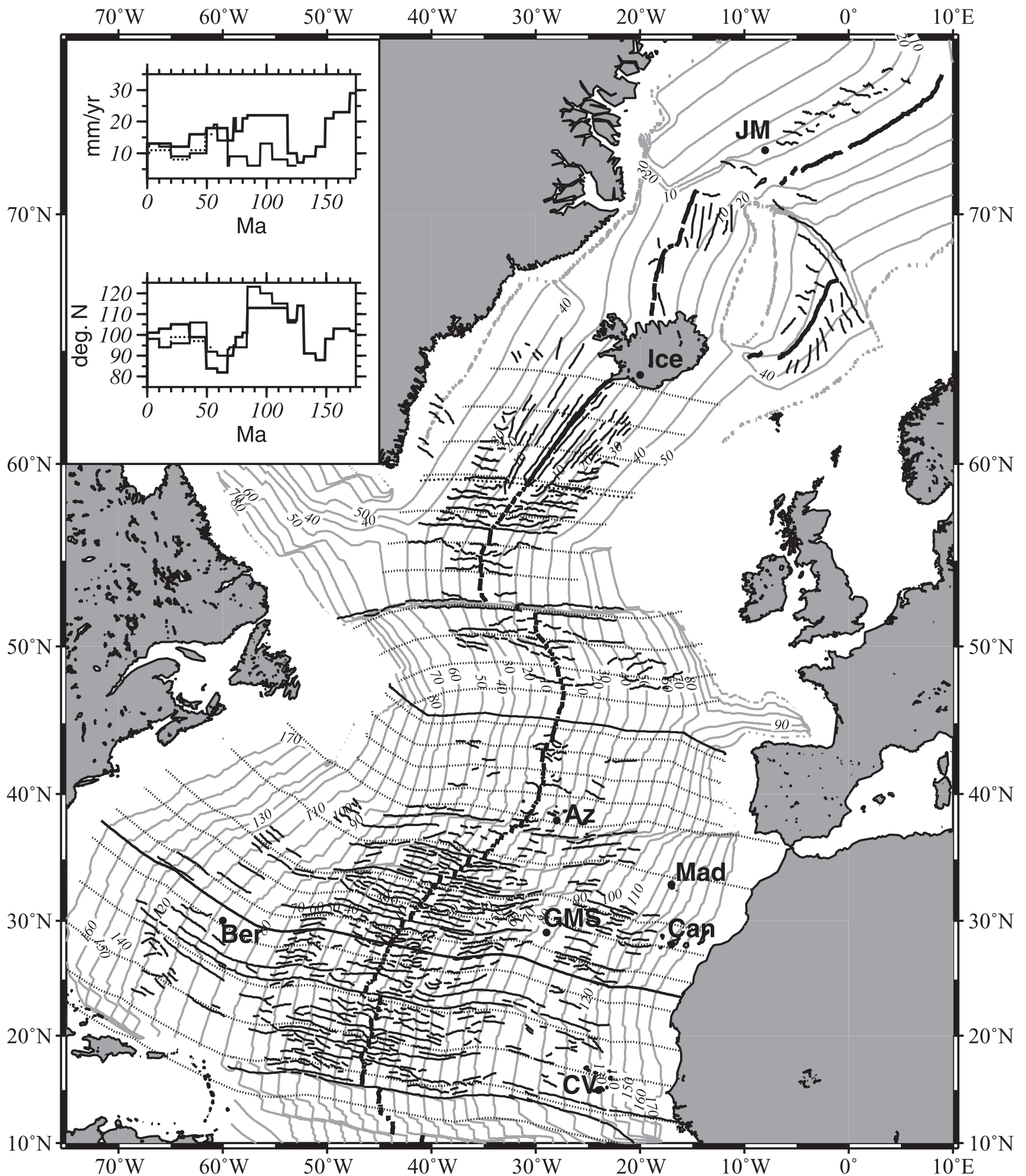

Figure 2. Gravity lineations identified in the northern and central Atlantic. Thin solid lines are traces of discontinuities. Thick lines are mid-ocean ridge axis. Dotted lines are flow lines drawn using Müller et al.'s [1997] finite poles of rotation. Shaded lines are isochrons from Müller et al.'s [1997] global age grid. Az, Azores; Ber, Bermuda; Can, Canary; CV, Cape Verde; GMS, Great Meteor; Ice, Iceland; JM, Jan Mayen; MAD, Madeira hot spots. Inset shows half-spreading rate and spreading direction for the three flow lines represented with the same pattern on map. 


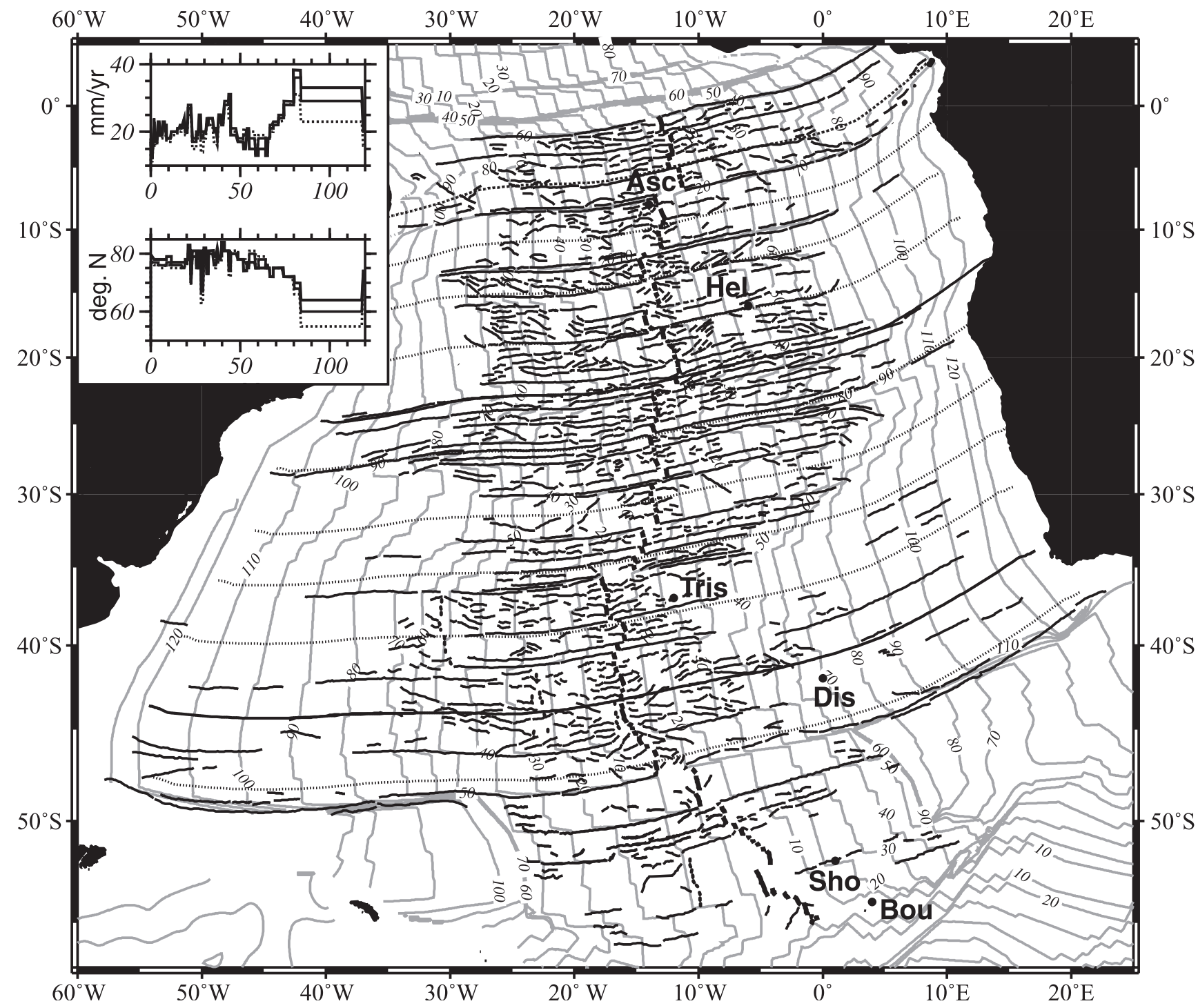

Figure 3. Gravity lineations identified in the South Atlantic. Asc, Ascension; Hel, Santa Helena; Tris, Tristan da Cunha; Dis, Discovery; Sho, Shona; Bou, Bouvet hot spots. Legend is the same as for Figure 2. Dashed lines are inferred fossil spreading centers on western flank of the ridge $\left(37^{\circ}-43^{\circ} \mathrm{S}\right.$ at $31^{\circ} \mathrm{W}, 42^{\circ}-47^{\circ} \mathrm{S}$ at $23^{\circ} \mathrm{W}, 44^{\circ}-47^{\circ} \mathrm{S}$ at $17^{\circ} \mathrm{W}$, and $52^{\circ}-55^{\circ} \mathrm{S}$ at $\left.10^{\circ} \mathrm{W}\right)$.

[10] RAD traces appear on the flanks of the Carlsberg Ridge (CAR) and Central Indian Ridge (CIR) at around $40 \mathrm{Ma}$, at the time of a major reorganization of the spreading system in the Indian Ocean between Chrons 22 and 18 (50-42 Ma) following the beginning of the collision between India and Eurasia (Figure 4). The reorganization was accompanied by a decrease in half-spreading rate from $\sim 65$ to $\sim 20 \mathrm{~mm} \mathrm{yr}^{-1}$ and by a $40^{\circ}$ clockwise change in spreading direction on the CIR [Patriat and Ségoufin, 1988]. The Southwest Indian Ridge (SWIR) displays prominent traces of transform faults and nontransform discontinuities on lithosphere younger than $\sim 80 \mathrm{Ma}$ (Figure 5). The segmentation is characterized by corridors, bounded by large transform faults, showing very different styles of RAD traces. For example, the corridor between about $33^{\circ} \mathrm{E}$ and $43^{\circ} \mathrm{E}$, close to the Marion hot spot, shows relatively few RAD traces. The corridor between $52^{\circ} \mathrm{E}$ (Gallieni $\mathrm{TF}$ ) and $61^{\circ} \mathrm{E}$ (Melville TF) displays RAD traces that have been stable since their formation near the triple junction, up to $50 \mathrm{Myr}$ ago. The flanks of the Southeast Indian Ridge (SEIR) show few off-axis traces of RADs. These are observed in the westernmost section, between the Indian Ocean Triple Junction and the St. Paul-
Amsterdam Islands, and in the Australia-Antarctic Discordance (AAD, Figure 6). A number of propagator pseudofaults also characterize the off-axis seafloor, with a convergence of the propagators toward the AAD [Sempéré et al., 1991; West et al., 1997, 1999].

[11] The off-axis lineations appear near $70 \mathrm{Ma}$ on the flanks of the Pacific-Antarctic Ridge (PAR, Figure 7). The lineations then disappear, near $30 \mathrm{Ma}$ just south of Udintsev FZ, and at progressively younger ages toward the south, resulting in a V-shaped boundary between seafloor affected by small-scale gravity lineations and smooth seafloor [Sahabi et al., 1996; Géli et al., 1997; Ondréas et al., 2001].

3.1.2. Length of axial second-order segments: Wavelength of the segmentation. [12] We analyze the length of axial segments of the Atlantic, Indian, and Pacific-Antarctic Ridges from sections of ridges where we have identified off-axis RAD traces. We measure the segment length from the bathymetry data wherever possible (northern MAR [Purdy et al., 1990; Gente et al., 1995; Sempéré et al., 1993], southern MAR [Fox et al., 1991; Michael et al., 1994]; PAR [Géli et al., 1997], SEIR [Sempéré et al., 


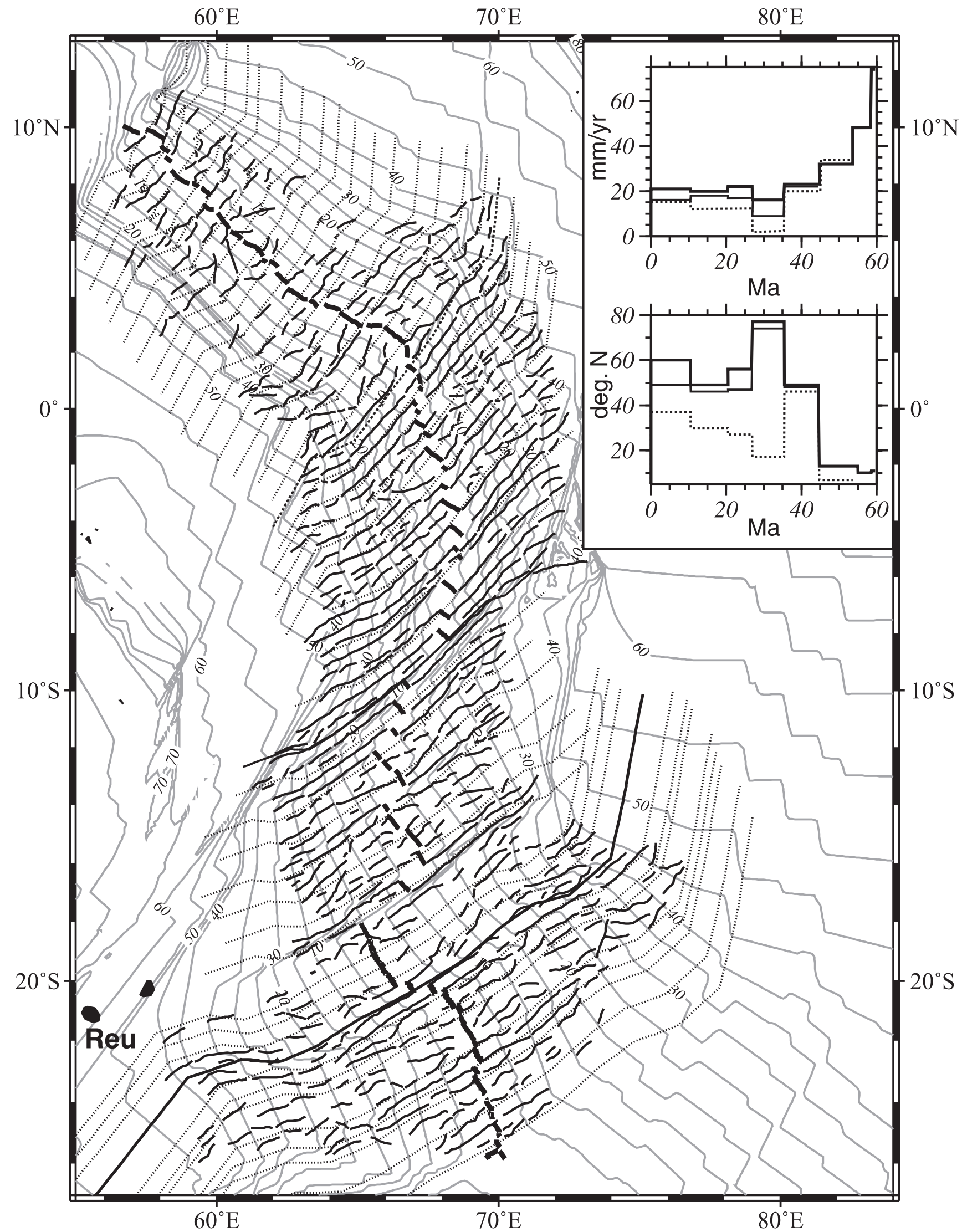

Figure 4. Gravity lineations in the central and northern Indian Ocean. Reu, Reunion hot spot. Legend is same as for Figure 2 . 


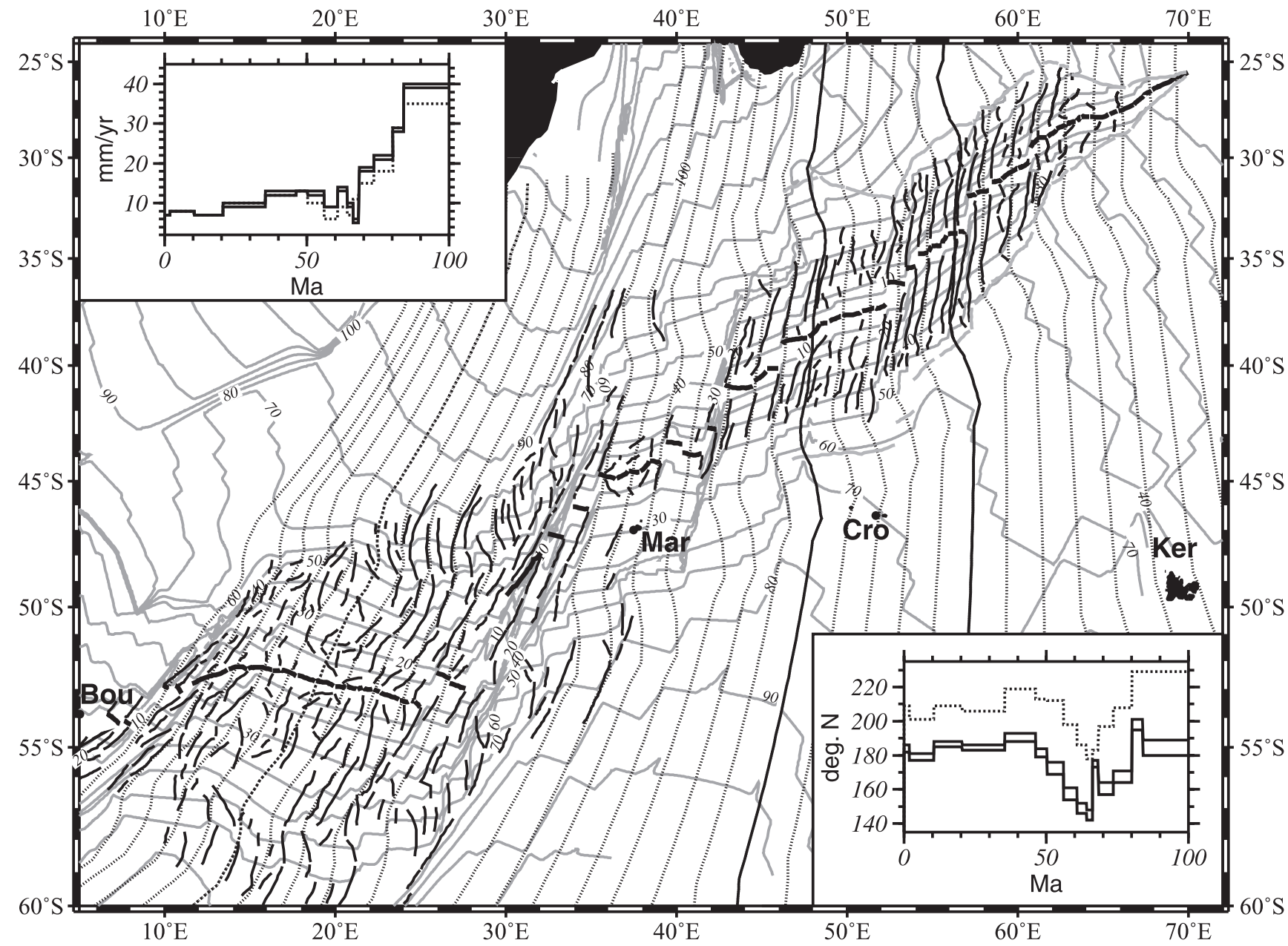

Figure 5. Gravity lineations in the western Indian Ocean. Cro, Crozet; Ker, Kerguelen; Mar, Marion hot spots. Legend is same as for Figure 2.

1997; Scheirer et al., 2000]), and from satellite altimetry data in sections of ridges not surveyed with multibeam bathymetry. The length of present-day axial segments is plotted against halfspreading rate based on NUVEL-1A present-day plate kinematic model [DeMets, 1993] (Figure 8). We also estimate an average segment length and a standard deviation for each major oceanic ridge (solid circles and bars in Figure 8). Segment lengths vary from $\sim 10$ to $240 \mathrm{~km}$, with an average of $52.5 \mathrm{~km}$. Fitting a straight-line regression through the data shows that the segment length does not increase with spreading rate for the slow to intermediate spreading ridges investigated here. There is a large variability of the segment length, however, with standard deviations for the major ridge systems of $20 \mathrm{~km}$ (CIR), $25 \mathrm{~km}$ (CAR, northern and southern MAR), $35 \mathrm{~km}$ (PAR and SWIR), and up to $44 \mathrm{~km}$ for the SEIR. This variability appears to be larger for the very slow spreading SWIR and the intermediate spreading PAR or SEIR than for the MAR or CIR. The CIR seems to have slightly shorter segments, with an average of $42 \pm 20 \mathrm{~km}$, probably because a great part of the ridge has to accommodate a high obliquity with respect to spreading. Some segments of the Southeast Indian Ridge and Pacific-Antarctic Ridge reach lengths of $150-200 \mathrm{~km}$, but these have often been digitized from altimetry data, which prevents to identify the small-offset overlapping spreading centers.

[13] Some sections of ridge have segments slightly shorter than adjacent sections, but this is not systematic. Cande et al. [1988, p. 13,481] notice about the southern MAR that "The four offsets associated with the Rio Grande fracture zone have a uniform spacing of $55 \mathrm{~km}$, and the three offsets associated with the Rio de Janeiro fracture zone between Chrons C34 and C22 have a uniform spacing of $80 \mathrm{~km}$." From a combined analysis of bathymetry and gravity data, Rommevaux-Jestin et al. [1997] observe that in the section of SWIR between the Atlantis II and Melville transform faults $\left(57^{\circ} \mathrm{E}-61^{\circ} \mathrm{E}\right)$, the bathymetric highs defining second-order segment centers coincide with mantle Bouguer anomaly (MBA) lows and are spaced apart by $\sim 60 \mathrm{~km}$. East of the Melville transform fault, the segmentation defined from bathymetric highs and lows does not always coincide with MBA variations, so that the second-order segmentation is more difficult to define. In that area the spacing between MBA lows can reach $130 \mathrm{~km}$ and up to $200 \mathrm{~km}$ for the section closest to the Indian Ocean Triple Junction [Rommevaux-Jestin et al., 1997]. Grindlay et al. [1998] observe a segment length of $42 \mathrm{~km}$ on average in the section of SWIR from $15^{\circ} 30^{\prime} \mathrm{E}$ to $25^{\circ} \mathrm{E}$.

3.1.3. Amplitude of the gravity lineations. [14] The amplitude of the gravity lineations is $\sim 30-50 \mathrm{mGal}$ from peak to trough (RMS about 15-25 mGal, Figures 1 and 9). It does not seem to depend on the offset at the RADs [Phipps Morgan and Parmentier, 1995]. In particular, some sections of ridge, such as the Kane to Atlantis TF section of the MAR, have well-marked second-order segmentation, despite small-offset discontinuities. Three factors, however, appear to have a significant effect on the amplitude of the signature of the segmentation in the gravity data. First, this amplitude seems to increase with decreasing spreading rate [Phipps Morgan and Parmentier, 1995]. The segmentation of the SWIR is often marked by variations in free-air gravity with 


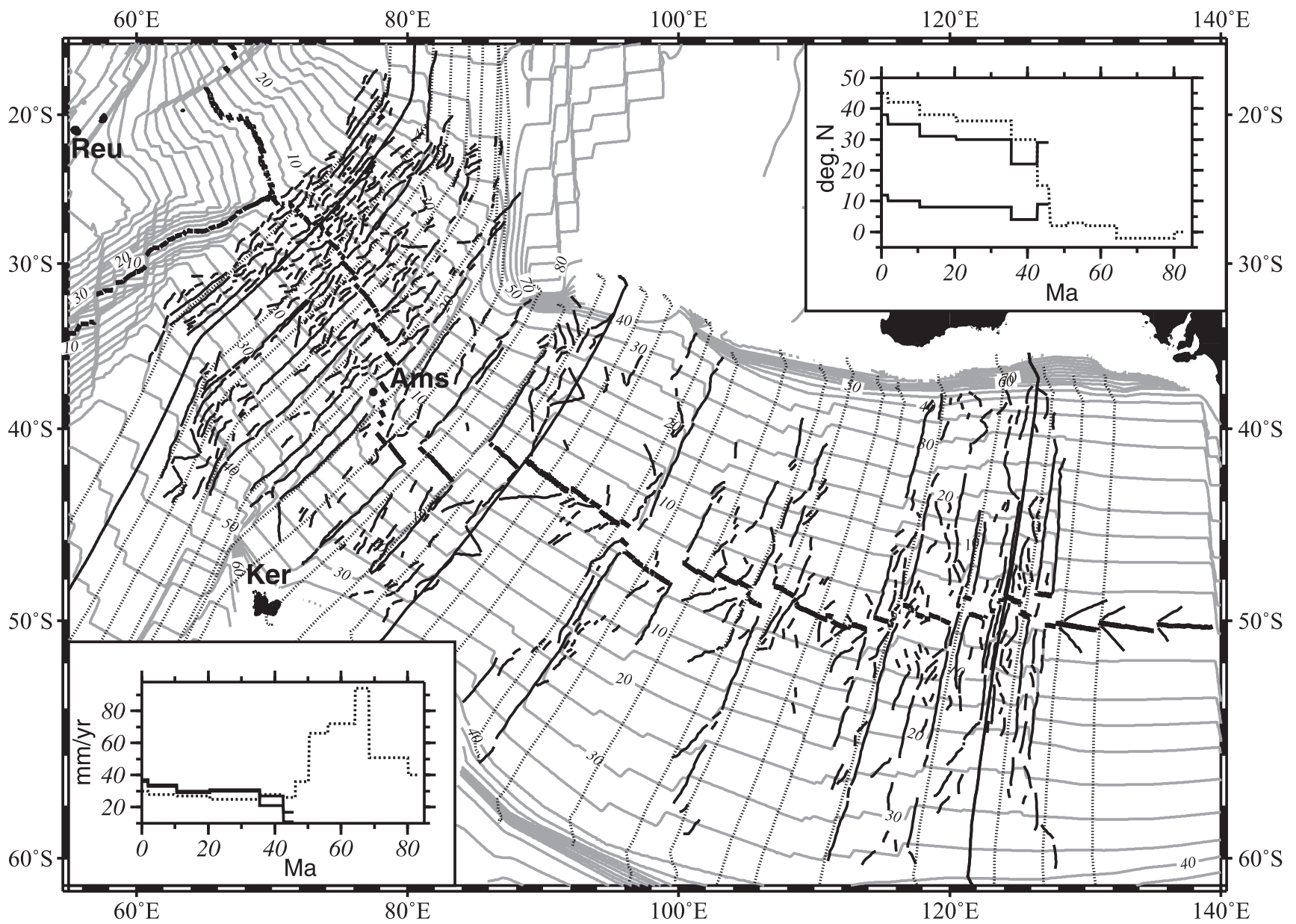

$60^{\circ} \mathrm{E}$

$80^{\circ} \mathrm{E}$

$100^{\circ} \mathrm{E}$

$120^{\circ} \mathrm{E}$

$140^{\circ} \mathrm{E}$

Figure 6. Gravity lineations in the eastern Indian Ocean. Ams, Amsterdam hot spot. Legend is same as for Figure 2.

peak-to-trough amplitudes of $\sim 20-25 \mathrm{mGal}$, larger than the 10 15 mGal amplitudes observed for the MAR [e.g., RommevauxJestin et al., 1997] (Figure 9). As noted in section 3.1.1, the signature of the segmentation disappears almost completely where the spreading rate reaches the "threshold" between axial valley and axial high [e.g., Sahabi et al., 1996] (Figure 10). At higher spreading rates, only large-offset transform faults and propagators leave traces in the gravity maps. Second, the amplitude of the gravity signature of the segmentation appears to be controlled by the thermal state of the ridge section. The segmentation signature is subdued in sections of ridge close to hot spots, such as on the MAR between $37^{\circ} \mathrm{N}$ and $47^{\circ} \mathrm{N}$ close to the Azores hot spot or on the CIR between $17^{\circ} \mathrm{S}$ and $19^{\circ} \mathrm{S}$, close to the Reunion/Rodrigues hot spot (Figures 2 and 4). To the contrary, the signature is well marked on the intermediate spreading SEIR in the AAD area, which also displays an axial valley resembling that of the MAR, compared to sections of the SEIR on either side of the AAD. Finally, some ridge sections, $\sim 1000 \mathrm{~km}$ in length, regionally oblique to spreading, tend to have larger-amplitude gravity lineations than adjacent sections which are perpendicular to spreading. To quantify this observation, the amplitude of the gravity lineations was measured off-axis along sections of isochron 6 (circa $20 \mathrm{Ma}$, from Müller et al.'s [1997] isochrons). The resulting profiles were projected perpendicular to spreading and are shown as a function of distance in Figure 9. The difference in RMS between the oblique sections and the orthogonal sections of the MAR or SWIR is $\sim 5 \mathrm{mGal}$. The combination of these three factors results in the absence of systematic variations of the gravity lineation amplitudes along one ridge, and induces important variations of the style of the segmentation even at uniform spreading rate.

\subsection{Evolution of the Axial Segmentation}

[15] A major observation in the gravity maps is that the patterns of the gravity lineations appear to be relatively homogeneous over 500 - to $1000-\mathrm{km}$-wide corridors of seafloor. This observation implies that the segments do not always evolve locally, independently from their neighbors, but that their evolution (birth, growth, survival, and death) is controlled regionally, at the scale of sections of ridges $\sim 1000 \mathrm{~km}$ long. These long sections of ridges and their associated off-axis seafloor define corridors in the same sense as those identified on the basis of uniform geophysical parameters characterizing the off-axis cooling [Hayes, 1988; Kane and Hayes, 1992; Hayes and Kane, 1994; Kane and Hayes, 1994]. In both cases the corridors are bounded by large fracture zones. Several typical cases of segmentation evolution can be described on the basis of the pattern of the discontinuity traces. We illustrate them here with a few examples, but these examples also apply to most flanks of midocean ridges. Two basic environments can be distinguished for the ocean ridges studied here: those which are far away from hot spots and those which appear to be close enough to be affected by hot spots. We exclude from the presentation the traces of second-order segmentation in sections of ridges very close to hot spots, or in fast spreading ridges, since we have shown that these 


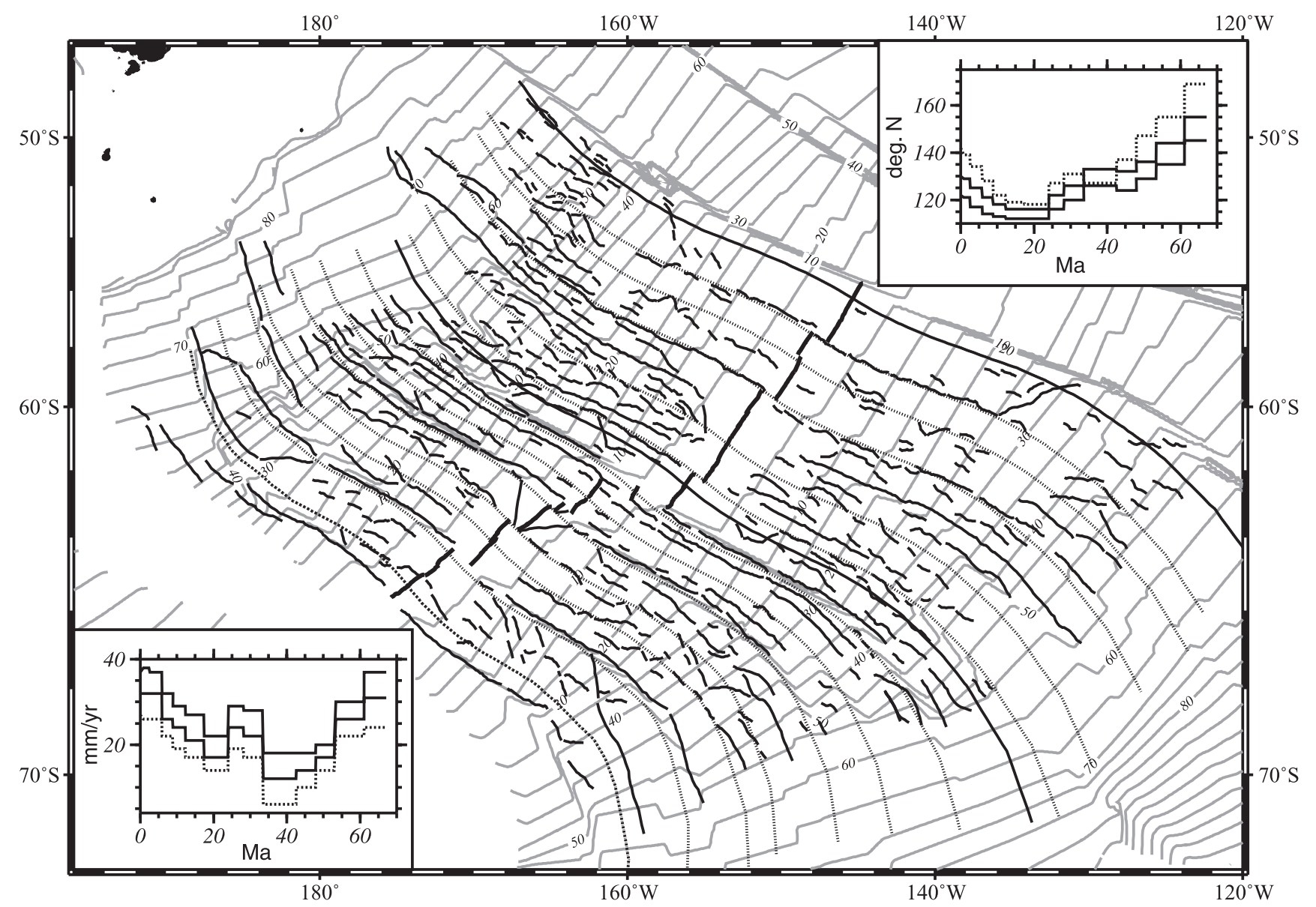

Figure 7. Gravity lineations in the southwest Pacific. Legend is same as for Figure 2.

are very difficult to analyze from the gravity data, and they have specific characteristics.

3.2.1. Ridge sections far from hot spots. [16] A typical example of evolution of the segmentation far from a hot spot is displayed by the section of MAR between the Kane and $15^{\circ} 20^{\prime} \mathrm{N}$ fracture zones (Figure 11a). This corridor shows seafloor with wavy gravity lineations which can be followed over $<20 \mathrm{Myr}$ and are not parallel to the major fracture zones. At the axis these lineations link to second-order axial segments typically described along the MAR. Lineations observed over a few million years and not parallel to spreading are interpreted as traces of shortlived segments which have migrated along the ridge axis. These segments can have a lifetime as short as 5-10 Myr. Divergence and merging of lineations correspond to the birth and death of ridge segments. This type of evolution is also observed, for example, on the northern MAR between the Atlantis and Kane Fracture Zones (Figures 1 and 2), on the SWIR between the Indomed and Gallieni $\mathrm{FZ}$ or between $15^{\circ} \mathrm{E}$ and $25^{\circ} \mathrm{E}$ (Figure 5), in the southern CIR (Figure 4), and in some sections of the southern MAR (Figure 3). A multibeam bathymetry and magnetic data analysis of the area between $20^{\circ} \mathrm{N}$ and $24^{\circ} \mathrm{N}$ reveals that the evolution of the segmentation of that part of the MAR is characterized by oblique discontinuity traces defining lozenges [Gente et al., 1995; Pokalny et al., 1996]. The results of this detailed study imply a migration of the discontinuities back and forth along the axis and a life span of the segments of the order of 10-20 Myr, supporting our observation that the segments are short-lived and that the segmentation evolves rapidly. The observation from detailed geophysical data can be easily extrapolated using the satellite altimetry data set, which is the basis of our approach.

[17] A second type of corridor showing the evolution of the segmentation far from hot spots is defined by long lineations, subparallel to the spreading direction, continuous over several tens of million years (Figure 11b). Continuous lineations parallel to flow lines are interpreted as traces of long-lived, second-order ridge segments which did not migrate along the axis and did not change in length. They are spectacular on the SWIR between the Gallieni and Melville FZs, where the segments display a uniform evolution in the last $50 \mathrm{Myr}$, during which nontransform discontinuity traces remain parallel to fracture zones. Similar lineations are also observed on the CAR and CIR between about 0 and $10^{\circ} \mathrm{S}$ (Figure 4), on the NMAR between the Atlantis and Oceanographer Fracture Zones for ages between $\sim 45 \mathrm{Ma}$ and Present (Figure 1) and between 150 and $90 \mathrm{Ma}$, as well as between the Kane and Atlantis FZs between 65 and 45 Ma (Figure 2). Such sections of stable segmentation are often regionally oblique to spreading. As mentioned in section 3.1.3, they are also associated to largeramplitude gravity lineations compared to the adjacent ridge sections. This type of lineations corresponds to the "crenulated seafloor" described by Phipps Morgan and Parmentier [1995].

3.2.2. Ridge sections affected by hot spots or "cold spots." [18] In regions very close to hot spots the lineations are difficult to pick because the gravity signature of the axial discontinuities is subdued. Lineations, however, are observed within 300-1000 km from hot spots, with an amplitude similar to those farther away from them. There, the evolution of the segmentation and axial geometry displays two characteristics. First, the axial segmentation tends to migrate away from hot 


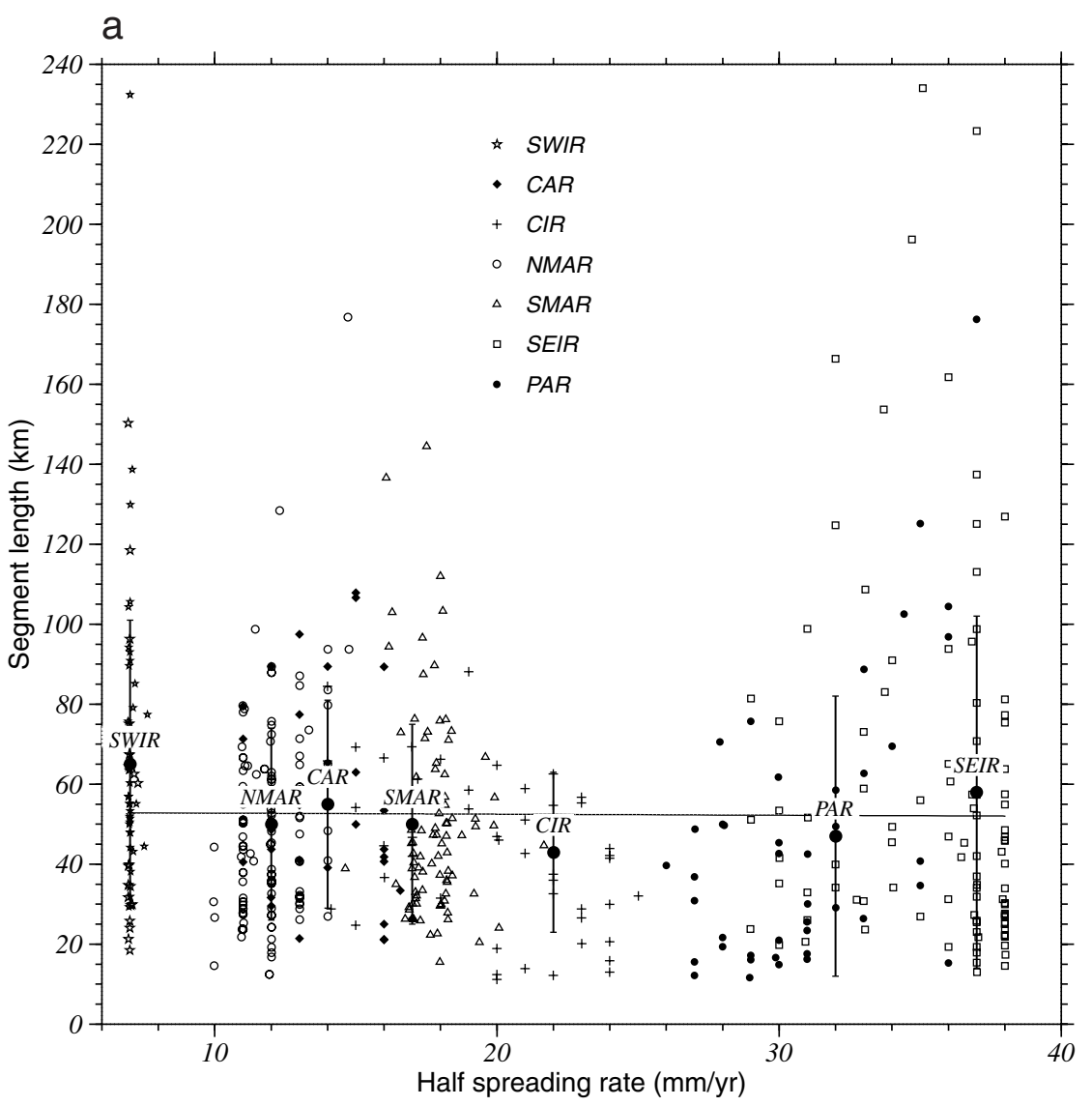

b

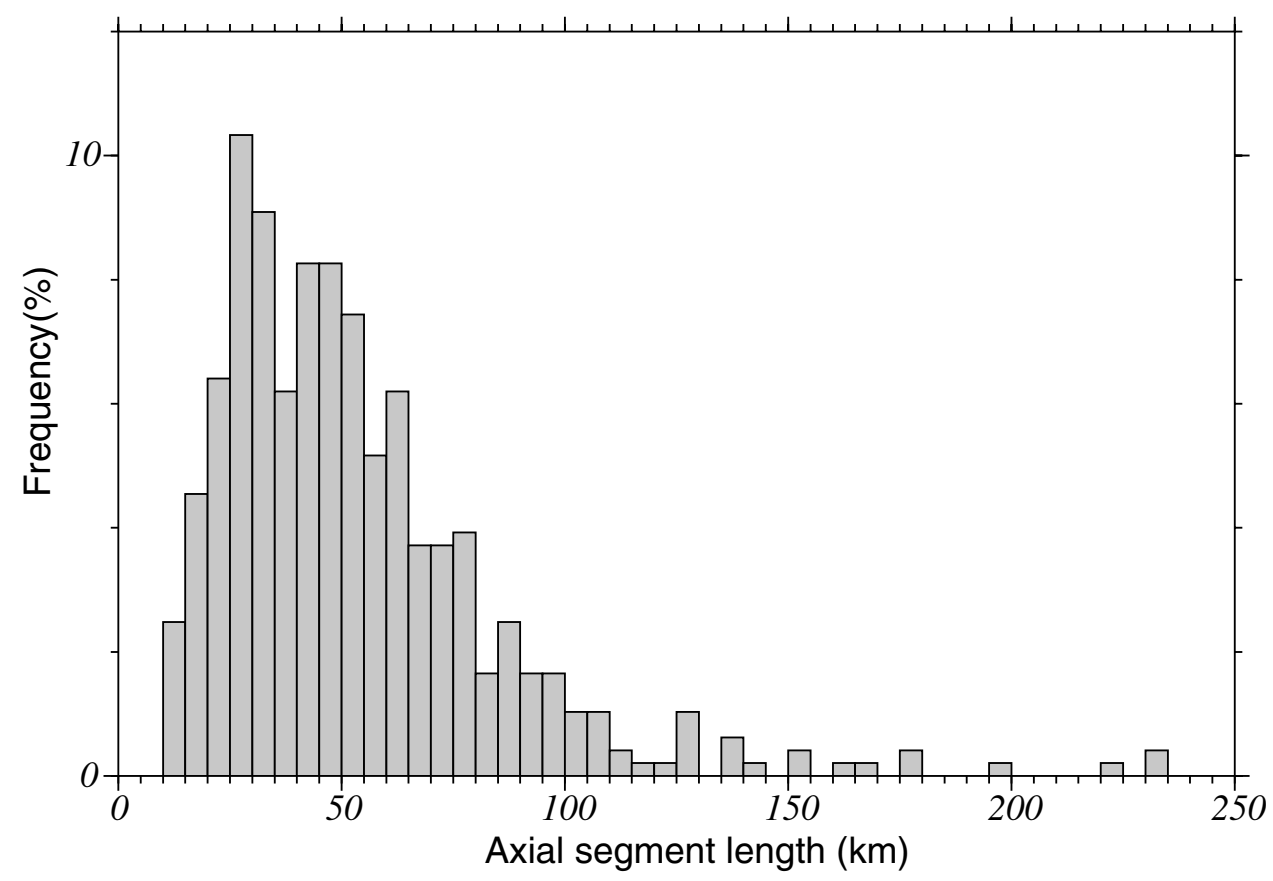

Figure 8. (a) Present-day axial segment length plotted versus half-spreading rate for the major plate boundaries. Dotted line is average of all segment lengths, at $52.5 \mathrm{~km}$. Solid line is straight line fitting the data. It is almost superimposed on the constant average. Solid circles and associated bars are regional averages with standard deviation. (b) Histogram of distribution of segment lengths. 


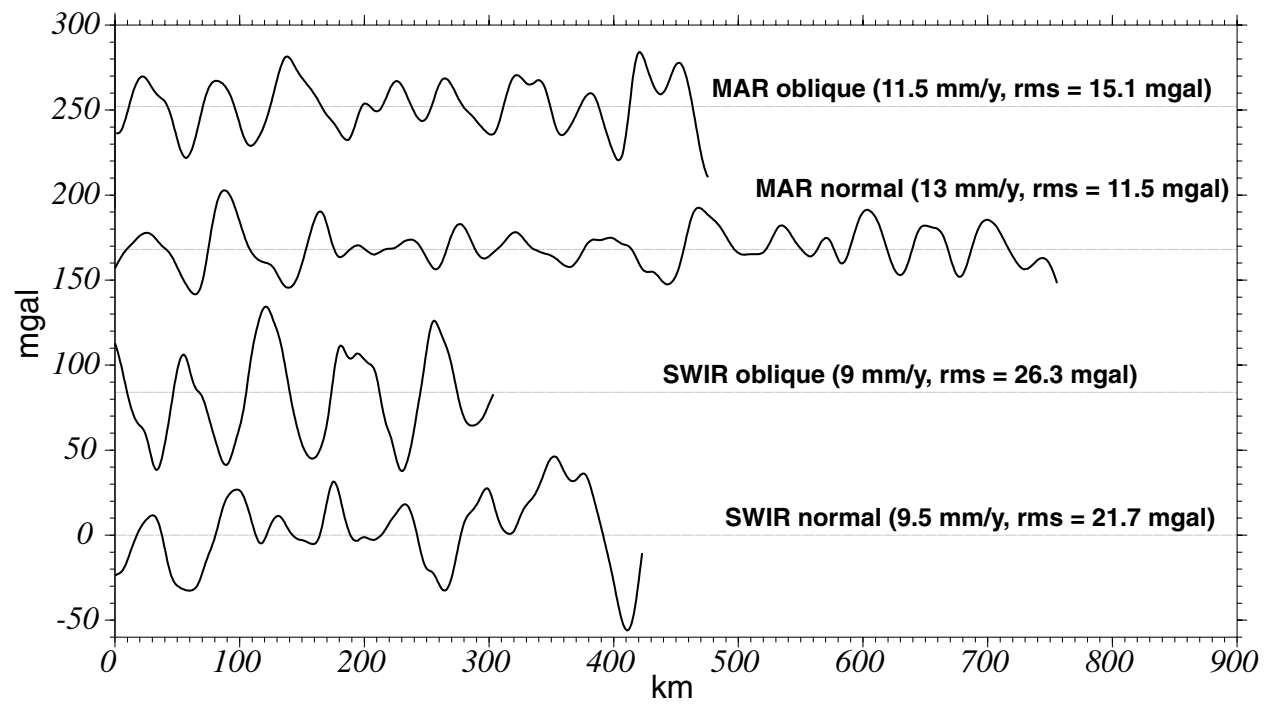

Figure 9. Amplitude of the gravity lineations on four profiles on the flanks of the MAR (top two curves) and the SWIR (bottom two curves), chosen in sections of the ridge regionally normal to spreading (MAR normal and SWIR normal) or oblique to spreading (MAR oblique and SWIR oblique). All profiles are along isochron 6 (circa $20 \mathrm{Ma}$, from Müller et al. [1997]).

spots or toward cold spots. Second, ridge sections near off-axis hot spots tend to spread asymmetrically, the ridge flank closest to the hot spot spreading slower than the other. In the following, we describe typical examples of these observations.

[19] One characteristic of these lineations is that they are often oblique to spreading, even though they are parallel to each other. The obliquity reflects a migration of the segmentation away from hot spots, often without any change in the length of the ridge segments. Such oblique lineations are especially clear in the South Atlantic near the Tristan da Cunha and Discovery hot spots (Figure 11c). Lineations are observed to converge toward the latitude of $44^{\circ} \mathrm{S}$. Between about $40^{\circ} \mathrm{S}$ and $44^{\circ} \mathrm{S}$, the segments migrate toward the south, in a direction away from the Tristan da Cunha hot spot, currently located at $37^{\circ} \mathrm{S}, 12^{\circ} \mathrm{W}$. Between $44^{\circ} \mathrm{S}$ and $47^{\circ} \mathrm{S}$, segments migrate toward the north, away from the Discovery hot spot currently located near $45^{\circ} \mathrm{S}, 6^{\circ} \mathrm{W}$. The northward migration seems to occur at different rates. Segments currently located near $44^{\circ} \mathrm{S}$ have migrated at a rate of $\sim 7 \mathrm{~mm} \mathrm{yr}^{-1}$ since $35 \mathrm{Ma}$, while segments currently located near $45^{\circ} \mathrm{S}$ have migrated north at a higher rate of $14 \mathrm{~mm} \mathrm{yr}^{-1}$, but only since $\sim 15$ Ma (isochrons from Müller et al. [1997]). It is also interesting to note that the large fracture zone observed near $45^{\circ} \mathrm{S}$ disappeared at $\sim 5 \mathrm{Ma}$, in favor of a northward migrating discontinuity. Although these discontinuities leave V-shaped traces comparable to those of

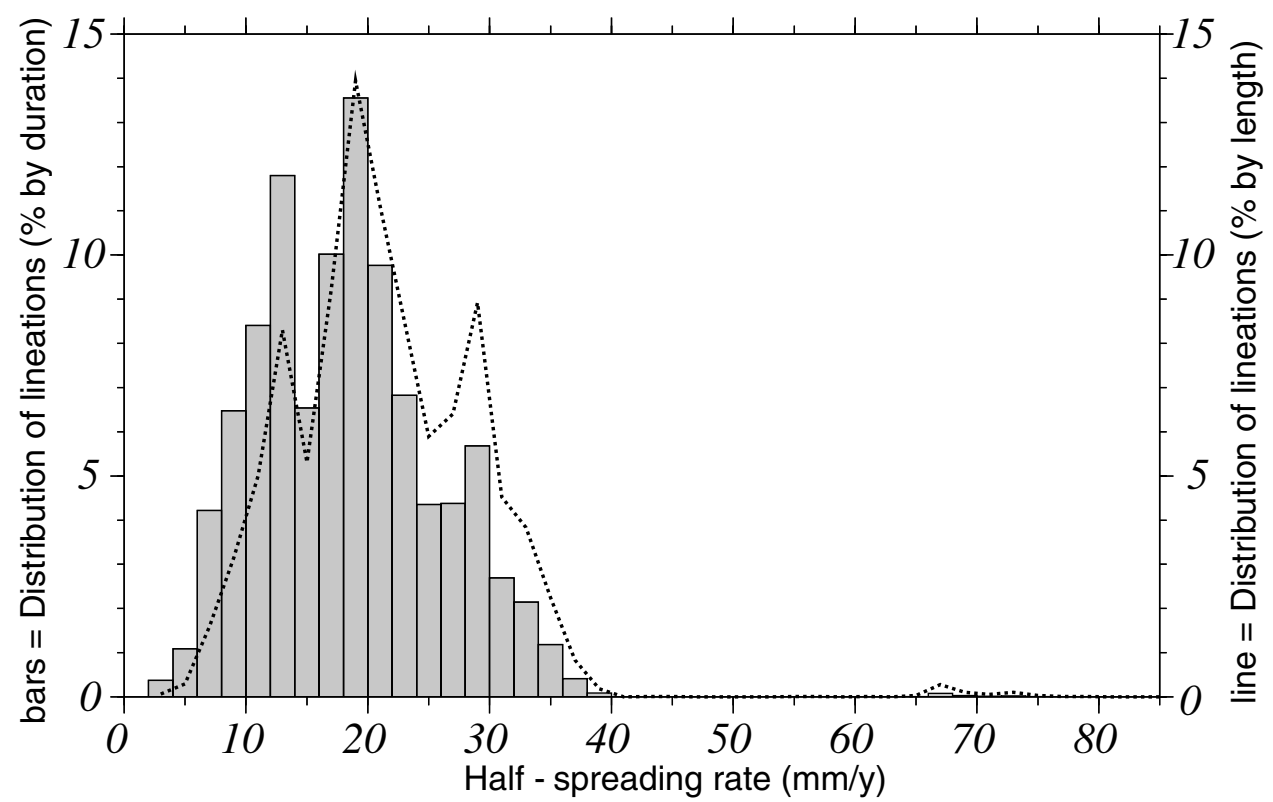

Figure 10. Distribution of the lineations corresponding to second-order segmentation with respect to half-spreading rate, estimated by cumulating their duration (bars) or their length (dotted line). 

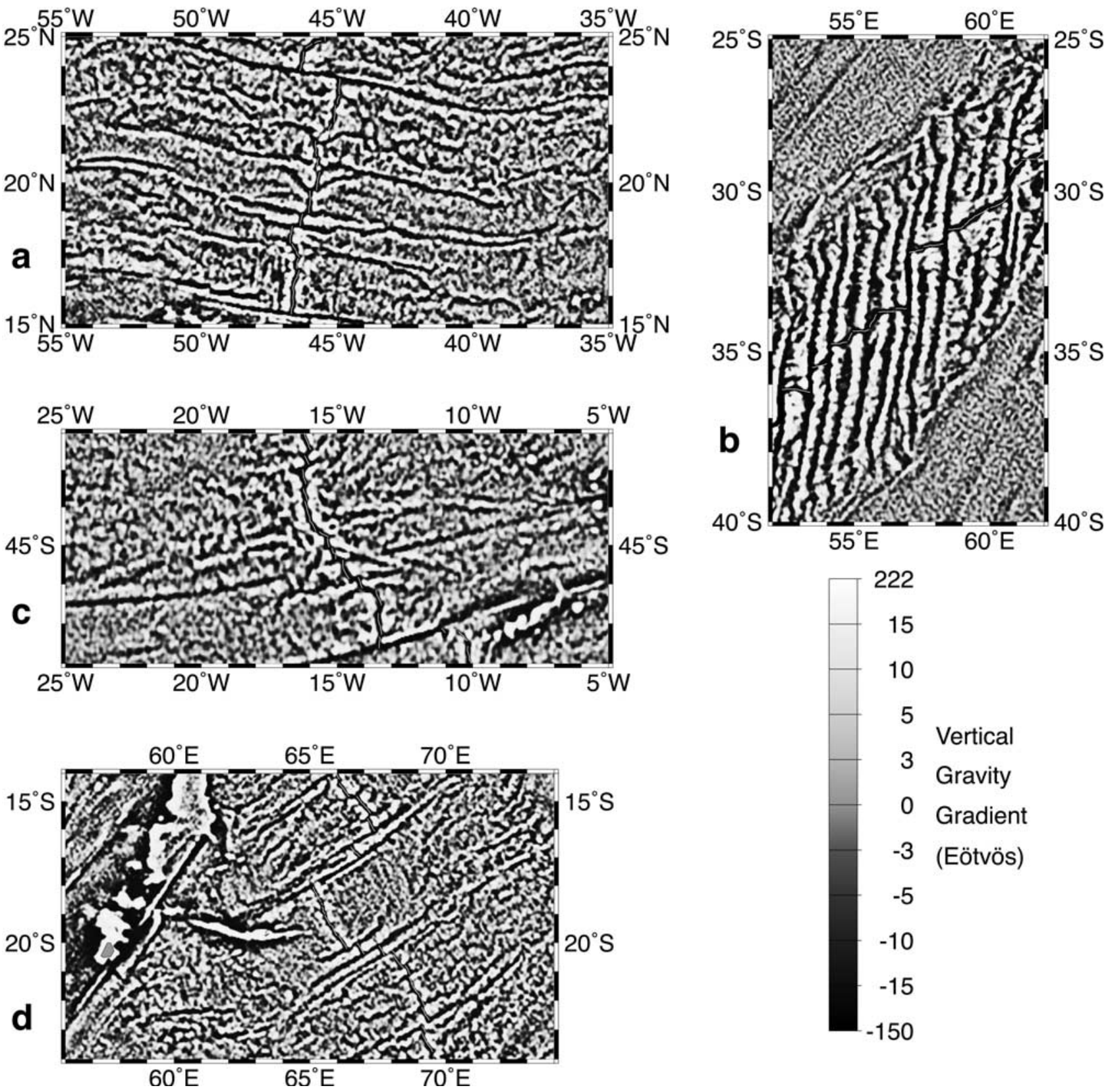

Figure 11. Maps of the vertical gravity gradient in areas typical of the segmentation evolution. (a) Kane to $15^{\circ} 20^{\prime} \mathrm{N}$ section of the MAR. (b) Gallieni to Melville TF section of the SWIR. (c) Southern Mid-Atlantic Ridge affected by hot spots. (d) Marie Celeste to Egeria section of the CIR. See color version of this figure at back of this issue.

\begin{abstract}
propagating ridges, we refer to "migrations" for these segments because the motion along axis is most often that of the whole segment and is not accompanied by the lengthening of one segment at the expense of its neighbor. Other "families" of oblique lineations are observed in several places in the South Atlantic, for example, near $6^{\circ} \mathrm{S}, 13^{\circ} \mathrm{W}$, near the Ascension hot spot, and near $18^{\circ} \mathrm{S}, 10^{\circ} \mathrm{W}$, near the Santa Helena hot spot. In the North Atlantic, similar lineations oblique to spreading are seen at $33^{\circ} \mathrm{N}$, near $33^{\circ} \mathrm{W}$ and $48^{\circ} \mathrm{W}$ (55-60 Ma, near the Great Meteor seamounts), and more recently near $30^{\circ} \mathrm{N}, 43^{\circ} \mathrm{W}$, and near the Azores around $37^{\circ} \mathrm{N}$ [Thibaud et al., 1998; Goslin and Triatnord Scientific Party, 1999] (on crust younger than $20 \mathrm{Ma}$ ). In the $30^{\circ} \mathrm{N}, 43^{\circ} \mathrm{W}$ area the migration of the discontinuities and associated segments toward the south is supported by a detailed bathymetric, gravity, and magnetic anomaly analysis [Sempéré et al., 1995].
\end{abstract}

[20] Oblique lineations and propagators are also clear on either side of the Australia-Antarctic Discordance (AAD, around $\left.127^{\circ} \mathrm{E}\right)$ on the SEIR (Figure 6). All these lineations, west and east of the AAD, converge toward a "cold spot" [Forsyth et al., 1987; Palmer et al., 1993], instead of migrating away from a hot spot. West of the AAD, the oblique gravity lineations are often associated to propagators converging toward the AAD, which have been studied by multibeam bathymetry, gravity, and magnetic data [Ma and Cochran, 1996; Sempéré et al., 1996; Shah and Sempéré, 1998; West et al., 1994, 1997]. East of the AAD, some propagators are also observed, pointing westward toward the AAD, but only where they coincide with large-offset discontinuities. The traces of the other discontinuities, most probably overlapping spreading centers, cannot be identified in the gravity data and would require detailed, multibeam bathymetry investigations. Another type of 
structures, however, clearly defines oblique lineations. They are a series of gravity highs, $15-40 \mathrm{mGal}$ in amplitude, spaced $30-50$ $\mathrm{km}$ apart along E-W isochrons, and are observed for example near $55^{\circ} \mathrm{S}, 135^{\circ} \mathrm{E}$, on the southern flank of the SEIR, and near $53^{\circ} \mathrm{S}$, $143^{\circ} \mathrm{E}$, on its northern flank. We speculate that these structures correspond to seamount chains [Gomez and Briais, 2001] because their signature in the gravity maps resembles that of seamount chains on the flanks of the East Pacific Rise [Scheirer and Macdonald, 1995; Scheirer et al., 1996; Gomez and Briais, 2000]. Since they only appear on one flank of the SEIR, they likely have formed off-axis, as the near-axis seamounts and seamount chains in the Rano Rahi seamount field near $18^{\circ} \mathrm{S}$ on the western flank of the EPR. The obliquity of these near-axis seamount chains could be interpreted in terms of migration of their sources toward the west, that is toward the AAD "cold spot." A lot more detailed analysis and sampling of these off-axis gravity highs is necessary to compare their source and evolution with the source and evolution of the SEIR second-order segmentation in this area. Such an analysis is beyond the scope of the present paper.

[21] The Iceland hot spot area has been the subject of many investigations of gravity lineations at various scales. Most previous studies searched the gravity maps and more detailed data sets for evidence of the evolution of the Iceland hot spot. This approach was guided by the idea that the V-shaped ridges south of Iceland reflect the southward migration of pulses in the activity of the hot spot [Vogt, 1971; White et al., 1995]. We set this idea aside and looked for gravity lineations around this hot spot with the same approach as used on the other ridges displaying small-scale gravity lineations. The segmentation of the Reykjanes Ridge axis at present is characterized by axial volcanic ridges arranged en échelon within an unsegmented axial valley [Talwani et al., 1971; Vogt, 1971; Laughton et al., 1979; Parson et al., 1993; Murton and Parson, 1993]. Small axial deeps and MBA highs are observed with a spacing of $\sim 130 \mathrm{~km}$ and could represent a subdued signature of ridge segmentation [Searle et al., 1998]. The off-axis bathymetry is marked by a series of ridges slightly oblique to the overall direction of the ridge but very oblique to spreading, forming V shapes pointing south [Vogt, 1971; Searle et al., 1998; Keeton et al., 1997]. On the flanks of the Reykjanes Ridge between $57^{\circ} \mathrm{N}$ and $63^{\circ} \mathrm{N}$, small-scale gravity lineations are observed, similar to those related to second-order segmentation farther south on the MAR, and we interpret them to be traces of second-order segmentation appearing at $\sim 35 \mathrm{Ma}$ (Figure 2). At that time, the direction of spreading did not change significantly, but the spreading rate decreased from a half rate of $\sim 11$ to $\sim 8 \mathrm{~mm}$ $\mathrm{yr}^{-1}$. The discontinuity traces are linear and subparallel to each other and to the spreading direction, suggesting that the segmentation was stable in the area during 10-20 Ma. The change between the typical signature of second-order segmentation and atypical, Vshaped ridges very oblique to spreading is diachronous. It occurs as early as $30 \mathrm{Ma}$ in the northern part near $60^{\circ} \mathrm{N}$ and at present in the south near $57^{\circ} \mathrm{N}$ (Figure 2). We suggest that the V-shaped lineations may have an origin similar to the other small-wavelength lineations because they have similar amplitude and because oblique lineations are commonly observed a few hundreds of kilometers from hot spots. North of Iceland, the most recent gravity grids showing the northern oceanic basins up to $82^{\circ} \mathrm{N}$ in latitude reveal small-scale lineations on the flanks of the Aegir fossil spreading center and on the flanks of Mohn's ridge (Figure 2 and Hwang et al. [1998]). We infer that these lineations north of Iceland are the traces of second-order segmentation of the corresponding ridges. The lineations on both flanks form $\mathrm{V}$ shapes pointing north, reflecting the migration of the second-order segments along the axis, away from the Iceland hot spot, in the same way as described above in the vicinity of hot spots in the central or south Atlantic. The lineations, however, are longer and easier to follow on the southern flank of Aegir spreading center and on the northern flank of Mohn's Ridge than on their opposite flank, a contrast which is likely due to asymmetric spreading.

[22] Another characteristic of sections of ridges close to hot spots is their asymmetric spreading, with slower spreading on the same flank of the ridge as the hot spot [Small, 1995; Müller et al., 1998]. From a comprehensive study of mid-ocean ridge asymmetry, Müller et al. [1998] show in particular that the asymmetry is not related to the absolute motion of the plate boundary nor is it a result of asymmetric depth-age behavior. A typical example of the hot spot-related asymmetry is again found in the South Atlantic between $40^{\circ} \mathrm{S}$ and $50^{\circ} \mathrm{S}$. The Tristan da Cunha and Discovery hot spots are located on the eastern flank of the MAR, which is observed to spread more slowly than the western flank by $\sim 20 \%$. This observation is also made farther south on the SMAR near the Shona hot spot. Some features identified from the altimetry maps on the western flank of the southern MAR actually resemble fossil spreading centers with a relict axial valley. Their signature consists of series of linear gravity lows $\sim 100 \mathrm{~km}$ in length, almost aligned, oriented subperpendicular to flow lines $\left(37^{\circ}-43^{\circ} \mathrm{S}\right.$ at $31^{\circ} \mathrm{W}, 42^{\circ}-47^{\circ} \mathrm{S}$ at $23^{\circ} \mathrm{W}, 44^{\circ}-47^{\circ} \mathrm{S}$ at $17^{\circ} \mathrm{W}$, and $52^{\circ}-55^{\circ} \mathrm{S}$ at $10^{\circ} \mathrm{W}$, Figure 3$)$. They correspond to periods of time when a marked spreading asymmetry is inferred by Müller et al. [1997, 1998]. One of the relict spreading axes was also identified as such by Small [1995]. We suggest that these features could represent evidence for successive jumps of sections of the southern MAR to the east toward the Tristan da Cunha, Discovery and Shona hot spots, although the identification of magnetic anomalies is incomplete in these areas, so that it is difficult to estimate how far the ridge axis may have jumped.

[23] This asymmetry results in the section of the ridge remaining closer to the hot spot than normal spreading would allow. After a long time, some ridges appear to have changed their geometry to satisfy this law. This is the case for the section of CIR between $18^{\circ} \mathrm{S}$ and $21^{\circ} \mathrm{S}$ (Marie Celeste and Egeria TF), near Rodrigues Ridge, which is offset to the west compared to the rest of the ridge (Figure 11d). This is also the case for the SEIR near Amsterdam-St. Paul, where the northern flank is spreading faster than the southern flank, resulting in the section of ridge being offset to the south compared to the adjacent parts of the SEIR. A similar observation is made for the Cocos-Nazca Ridge near the Galápagos Islands. North of Iceland, the spreading asymmetry is documented by magnetic anomaly analyses on the fossil Aegir Ridge and on Mohn's Ridge [Vogt et al., 1970], as well as on the Kolbeinsey Ridge [Appelgate, 1997]. Spreading on the Aegir spreading center was faster on the eastern side, and that on Mohn's and Kolbeinsey Ridges is faster on the western side.

\section{Discussion}

[24] The comprehensive analysis of the second-order axial segmentation, through the mapping of its gravity signature, reveals that the geometry and evolution of the segmentation of mid-ocean ridges appear to be controlled by a small number of factors, acting at a regional scale. We discuss here the factors which seem to play a major role in shaping the flanks of mid-ocean ridges, either by controling how second-order ridge segments individualize and crustal production varies along axis or by controlling how these variations are (or are not) frozen in the off-axis lithosphere.

\subsection{Mantle Versus Lithospheric Control on the Geometry and Evolution of the Segmentation}

[25] Segmentation has been observed on all flanks of ridges where the axial morphology is characterized by a relatively deep axial valley. Two hypotheses have been proposed for the origin of ridge segmentation on these slow spreading, or cold ridges [Tucholke et al., 1997]. One "tectonic" hypothesis attributes the basic three-dimensional structure of slow spreading ridges to 
processes intrinsic to mechanical extension of the lithosphere [Mutter and Karson, 1992]. In this case the segments are defined and bounded by large detachment faults which accommodate extension both along flow lines (parallel to spreading) and along isochrons (along-axis extension), and the segmentation is controlled by the pattern of lithospheric extension between magmatic phases. The mantle then flows passively upward as a result of plate separation. The alternative, "magmatic" hypothesis suggests that the segmentation is defined and controlled by the three-dimensional (3-D) pattern of mantle upwelling and melt production, so that segment centers receive more melt than segment ends.

[26] Our observations do not support the tectonic hypothesis. The striking homogeneity revealed by our analysis in the behavior of the axial segmentation, within 500-1000-km-long ridge sections limited by large transform faults, suggests a deep origin for the segmentation and probably a control by mantle processes. In particular, some ridge sections have a segmentation stable in space and time for 30-50 Myr, a timescale incompatible with a control of the segmentation by detachment faults, since the latter are likely to be redefined more frequently. Tucholke et al. [1997] also point out that this hypothesis does not explain how ridge discontinuities marked in the axial crustal structure are maintained while the offset across them is reduced to zero, and even reversed, as they observe near $26^{\circ} \mathrm{N}$ on the MAR. Mutter and Karson [1992, p. 633] mention that the 3-D nature of mantle upwelling must "influence the style and pattern of deformation such that large-scale brittle deformation is favored away from the warmer centers of upwelling". We agree with Tucholke et al. [1997] that the pattern of mantle upwelling is the dominant factor that controls the origin and evolution of midocean ridge segmentation, and therefore we prefer the magmatic hypothesis. The latter is also supported by the frequent migration of ridge segments, away from a nearby hot spot. That segments can both migrate and preserve their length and offsets cannot be accounted for by extensional processes but may be better accounted for by along-axis migration of the mantle sources beneath the ridge segments. Also the tectonic hypothesis implicitly suggests that a significant amount of extension occurs along-axis (Mutter and Karson's Figure 9 has $\sim 40 \%$ axis-parallel extension), which is only possible in regions where the ridge shows a strong regional obliquity. The observations show that ridge obliquity seems to affect the amplitude of the segmentation signature, but that it has little effect on its wavelength (Figure 9). Most sections of the southern MAR are normal to spreading but display a typical ridge segmentation. The northern part of the CIR is very oblique to spreading, but the segment length only decreases by a few kilometers there compared to the southern, spreading normal sections (Figure 4).

\subsection{Passive Versus Dynamic Mantle Upwelling Beneath Axial Segments}

[27] After selecting the hypothesis which explains most alongaxis crustal thickness variations by mantle upwellings beneath the segment midpoints, we still face the choice between two currently debated possibilities. Either the mantle is passively advected by the plate separation or it generates dynamic upwellings. The "passive" hypothesis assumes that the geometry of the mantle upwelling is controlled by that of the plate boundary [Phipps Morgan and Forsyth, 1988]. In this model the mantle flow beneath the axis directly reflects the thermal structure of the lithosphere as determined by its off-axis cooling. The "dynamic" hypothesis suggests that the intrinsically unstable mantle thermal or chemical structure generates upwellings that feed the spreading segments. The upwellings may be either diapirs of buoyant, partially molten mantle [Whitehead et al., 1985; Crane, 1985; Schouten et al., 1985] or the rising plumes of a thermally driven convective flow beneath the ridge axis [Sparks et al., 1993; Rabinowicz et al., 1993; Rouzo et al., 1995]. The uniformity that we observe in the segment length over a wide range of mid-ocean ridges and in the space and time evolution of the segments supports the dynamic hypothesis. Kincaid et al. [1996] and Magde et al. [1997] analyze the effect of the geometric segmentation on the mantle flow. In their experimental and numerical models, plate-driven flow dominates the buoyant flow near large transform fault offsets. Similar numerical models, however, fail to reproduce the $50-100 \mathrm{~km}$ characteristic wavelength of the magmatic segmentation of slow spreading ridges with small offsets. In this case, the observed large crustal thickness variations in the absence of ridge offset are tentatively explained by magma focusing toward segment centers, from 2-D mantle upwellings, driven by the slope in the brittleductile boundary [Magde et al., 1997]. This hypothesis returns to the tectonic model discussed in section 4.1. In the convection model the segmentation may adjust to the pattern of mantle convection, so that the geometry of the axis depends on the mantle upwelling, and not the reverse. This hypothesis satisfactorily explains the back and forth, along-axis migration of segments in some corridors, and the change of discontinuity offsets with no destruction of the magmatic segmentation.

\subsection{Role of the Large-Scale Mantle Flux Near Hot Spots or Cold Spots}

[28] The systematic migration of series of ridge segments away from hot spots is one of the most prominent observations from the altimetry data. In the southern Atlantic the migrating ridge segments do not change length, and their discontinuities, when they exist, appear to remain about the same, although the magnetic anomalies are often difficult to identify in these environments (Figure 3). The migration of ridge segments west of the AAD seems to be accompanied by the propagation of ridge segments at the expense of their eastern neighbors. For both ridges we observe some large transform faults which are not affected by the discontinuity migration and have traces that follow small circles of the Euler plate rotation and some transform faults which are destroyed by the segment migration and turn into migrating, nontransform discontinuities. In many cases, the ridge segments appear to be passively carried away by a larger flow coming from the hot spot or going toward a cold spot (either sides of the AAD). This observation suggests that hot spot material does not merely "sink" into the ridge axis but that the mantle flux originating from the hot spot is strong enough to affect the dynamics of the ridge segmentation.

[29] Another striking observation is the asymmetry of spreading near off-axis hot spots, which was already noted by Small [1995] and Müller et al. [1998]. Small [1995] suggests that spreading asymmetry by ridge jumps may result from the weakening of the off-axis lithosphere by the excess temperature near the hot spot. In several cases, however, the asymmetry does not seem to involve ridge jumps and appears to be more continuous, suggesting a dynamic effect of the large-scale mantle flux away from the hot spot. The interaction of material originating from hot spots and nearby ridge axes leads to other complex structures, including aseismic ridges that are oblique to both the spreading direction and the plate absolute motions, such as the Shona Ridge in the South Atlantic [Small, 1995] or the Hollister Ridge off the PAR [Géli et al., 1998]. A more careful analysis should try and separate the dynamic effect of the hot spots on the ridge axis and the mixing of mantle sources in the basalts on the ridge axis and in the off-axis aseismic ridges. Such a detailed analysis is beyond the scope of the present paper.

\subsection{Role of the Spreading Rate on the Signature of the Axial Segmentation}

[30] The off-axis signature of the second-order segmentation is clear only for ridges with an axial valley. For ridges where the axial morphology is characterized by a shallow axial valley, rifted highs, or a ridge crest, which are intermediate to fast spreading ridges, the signature is subdued. For these ridges, only large-offset transform 
faults, overlapping spreading centers (OSCs), or propagators result in the production of a significantly thinner crust and leave off-axis traces. Figure 10 represents the distribution of the discontinuities as a function of the half-spreading rate, compared either by the duration or by the length of the RAD traces. It shows that in the investigated ocean basins the traces of the second-order discontinuities tend to disappear when the half-spreading rate is over 30 $\mathrm{mm} \mathrm{yr}^{-1}$. Since we have not considered the basins where only the large fracture zones are observed, like most of the Pacific, the diagram is only valid in terms of second-order discontinuities. There seems to be a correlation between the ability of the oceanic lithosphere to record the variations in crustal production off-axis, producing gravity lineations, and its ability to develop an axial valley. The two processes, however, are usually attributed to different causes. As discussed in section 1, along-axis, crustal thickness variations may be attributed to three-dimensional mantle upwelling and melt generation beneath the ridge axis, leading to variations in the magma budget along axis [Kuo and Forsyth, 1988; Lin et al., 1990; Rouzo et al., 1995]. Axial morphology is inferred to depend on the rheology of the axial lithosphere, itself controlled by the thickness of the crust and the temperature of the crust and upper mantle [Phipps Morgan et al., 1987; Chen and Morgan, 1990a, 1990b]. Models of extension of the axial lithosphere show that the crustal thickness itself may determine the morphology of the axis, with a threshold in the crustal thickness or temperature of the upper mantle above which no axial valley develops [Chen and Morgan, 1990a, 1990b; Phipps Morgan and Chen, 1993; Neumann and Forsyth, 1993; Shaw and Lin, 1996]. Some models of mantle convection predict that the structure of the mantle flow beneath the axis should be 2-D under fast spreading or hot ridges, and 3-D beneath slow-spreading or cold ridges [Parmentier and Phipps Morgan, 1990; Jha et al., 1994; Phipps Morgan and Parmentier, 1995]. The correlation between the existence of an axial valley and the observation of off-axis crustal thickness variations suggests that the signature of the segmentation may also depend on how the crustal material is redistributed along axis, as already suggested by Bell and Buck [1992].

[31] The signature of the axial segmentation depends not only on the spreading rate but also on the thermal state of the ridge axis. This has long been noticed along the Reykjanes Ridge, where axis discontinuities are not observed close to the Iceland hot spot [Talwani et al., 1971; Laughton et al., 1979] or in the AustraliaAntarctica Discordance section of the SEIR, where axial morphology and segmentation are not typical of the intermediate spreading rate [Weissel and Hayes, 1974]. Such variations in the style of segmentation are also clearly observed in the central Atlantic or the Southwest Indian Ridge, where adjacent corridors of seafloor display very contrasted lineation patterns, whereas the half spreading rate does not differ by more than 2 or $3 \mathrm{~mm} \mathrm{yr}^{-1}$ (Figures 1, 2, and 5). Such contrasted behaviors are usually separated by large transform faults, as in the SWIR but may also be limited by relatively small-offset transform faults, such as the Atlantis TF.

\subsection{Role of the Lithosphere in the Amplitude of the Gravity Signal}

[32] Two observations suggest that the lithosphere plays another role in the final signature of the second-order segmentation. First, the amplitudes of the gravity and bathymetry signature of the second-order segmentation are larger along oblique sections of ridges (Figure 9). This observation suggests either that larger-offset discontinuities, even when they are not real transform faults, lead to larger crustal thickness variations or that a succession of offsets implies or reflect a mantle upwelling pattern different from that beneath sections of ridges relatively straight and perpendicular to spreading. The former hypothesis is ruled out because the amplitude of the gravity anomaly is not correlated with individual discontinuity offsets. Second, the amplitude of the signature is also larger at slower spreading rates, suggesting that a thicker, cooler lithosphere beneath the axial region inhibits the redistribution of crustal material along-axis and favors the record of the along-axis variations in crustal production.

\section{Conclusions}

[33] We provide a synoptic description of the main characteristics of the crustal structure variations induced by mid-ocean ridge axial discontinuities, as well as their evolution in time, over the flanks of the Mid-Atlantic, Indian, and Pacific-Antarctic Ridges. The second-order segment length does not appear to vary with the spreading rate for the slow to intermediate spreading ridges investigated here. The amplitude of the gravity signal associated with off-axis discontinuity traces increases with the obliquity of the ridge to spreading and decreases with spreading rate and with the proximity of a ridge section to a hot spot. The evolution of the segmentation in time generates patterns in the gravity lineations which are very homogeneous over 500 - to 1000 - $\mathrm{km}$-large corridors bounded by large fracture zones. Far from hot spots, corridors are characterized either by segments bounded by discontinuities migrating back and forth along the axis, implying a lifetime of 10-30 Myr for the segments, or by segments and discontinuities very stable in space and time, surviving for 40-50 Myr. Closer to hot spots, the segmentation is affected in two ways. First, segments tend to migrate along-axis away from hot spots or toward cold spots. Second, asymmetric spreading tends to keep sections of ridges closer to hot spot than normal spreading would. These observations support the hypothesis that ridge segmentation and its evolution are controlled primarily by the dynamics of mantle upwelling beneath the ridge axis. The lithospheric control on the generation and evolution of the segmentation seems to be secondary for the slow to intermediate spreading ridges where we could identify and follow the discontinuity traces. An increase in spreading rate or in regional mantle temperature appears to lead to the disappearance not only of the axial valley for rifted highs or ridge crest but also of the crustal thickness variations, preventing us from analyzing the evolution of the segmentation from its gravity signature. Our analysis provides observational constraints for further models of crustal production along ridges, as presented in the companion paper by Rabinowicz and Briais [2002].

[34] Acknowledgments. The initiation of this work benefited from discussions with and suggestions by Jean-Christophe Sempéré and Stéphane Rouzo. We thank Jian Lin and an anonymous reviewer for their constructive reviews. This research was partly funded by INSU Programme "Dorsales".

\section{References}

Appelgate, B., Modes of axial reorganization on a slow-spreading ridge: The structural evolution of Kolbeinsey Ridge since 10 Ma, Geology, 25, 431-434, 1997.

Barclay, A. H., D. R. Toomey, and S. C. Solomon, Seismic structure and crustal magmatism at the Mid-Atlantic Ridge, $35^{\circ} \mathrm{N}, J$. Geophys. Res., 103, 17,827-17,844, 1998 .

Bell, R. E., and W. R. Buck, Crustal control of ridge segmentation inferred from observations of the Reykjanes Ridge, Nature, 357, 583-586, 1992.

Cande, S. C., J. L. LaBrecque, and W. F. Haxby, Plate kinematics of the South Atlantic: Chron C34 to Present, J. Geophys. Res., 93, 13,47913,492, 1988.

Carbotte, S., S. M. Welch, and K. C. Macdonald, Spreading rates, rift propagation, and fracture zone offset histories during the past $5 \mathrm{Myr}$ on the Mid-Atlantic Ridge; $25^{\circ}-27^{\circ} 30^{\prime} \mathrm{S}$ and $31^{\circ}-34^{\circ} 30^{\prime} \mathrm{S}$, Mar. Geophys. Res., 13, 51-80, 1991.

Cazenave, A., B. Lago, and K. Dominh, Geoid anomalies over the northeast Pacific fracture zones from satellite altimeter data, Geophys. J. R. Astron. Soc., 69, 15-31, 1982.

Cazenave, A., P. Schaeffer, M. Berge, C. Brossier, K. Dominh, and M. C. Gennero, High-resolution mean sea surface computed with altimeter data of ERS-1 (geodetic mission) and TOPEX-Poseidon, Geophys. J. Int., 125, 696-704, 1996. 
Chen, Y., and W. J. Morgan, Rift valley/no rift valley transition at midocean ridges, J. Geophys. Res., 95, 17,571-17,581, 1990a.

Chen, Y., and W. J. Morgan, A nonlinear rheology model for mid-ocean ridge axis topography, J. Geophys. Res., 95, 17,583-17,604, 1990b.

Cormier, M. H., R. S. Detrick, and G. M. Purdy, Anomalously thin crust in oceanic fracture zones: New seismic constraints from the Kane fracture zone, J. Geophys. Res., 89, 10,249-10,266, 1984.

Crane, K., The spacing of rift axis highs: Dependence upon diapiric processes in the underlying asthenosphere?, Earth Planet. Sci. Lett., 72, 405-414, 1985.

DeMets, C., Earthquake slip vectors and estimates of Present-day plate motion, J. Geophys. Res., 98, 6703-6714, 1993.

Forsyth, D. W., R. L. Ehrenbard, and S. Chapin, Anomalous upper mantle beneath the Australian-Antarctic discordance, Earth Planet. Sci. Lett., 84, $471-478,1987$.

Fox, P. J., N. R. Grindlay, and K. C. Macdonald, Mid-Atlantic Ridge $\left(31^{\circ} \mathrm{S}-34^{\circ} 30 \mathrm{~S}\right)$ : Temporal and spacial variations of accretionary processes, Mar. Geophys. Res., 13, 1-20, 1991.

Géli, L., et al., Evolution of the Pacific-Antarctic Ridge south of Udintsev Fracture Zone, Science, 278, 1281-1284, 1997.

Géli, L., D. Aslanian, J.-L. Olivet, I. Vlastelic, L. Dosso, H. Guillou, and H. Bougault, Location of Louisville hotspot and origin of Hollister ridge: Geophysical constraints, Earth Planet. Sci. Lett., 164, 31-40, 1998.

Gente, P., R. Pockalny, C. Durand, C. Deplus, M. Maia, G. Ceuleneer, C. Mével, M. Cannat, and C. Laverne, Characteristics and evolution of the segmentation of the Mid-Atlantic Ridge between $20^{\circ} \mathrm{N}$ and $24^{\circ} \mathrm{N}$ during the last 10 million years, Earth Planet. Sci. Lett., 129, 55-71, 1995.

Gomez, O., and A. Briais, Near-axis seamount distribution and its relation with the segmentation of the East Pacific Rise and northern PacificAntarctic Ridge, $17^{\circ} \mathrm{N}-56^{\circ} \mathrm{S}$, Earth Planet. Sci. Lett., 175, 233-246, 2000.

Gomez, O., and A. Briais, Analysis of off-axis volcanism East of the Australia-Antarctic Discordance (abstract), J. Conf. Abst. [CD-ROM], $6(1), 2001$.

Goslin, J., and Triatnord Scientific Party, Extent of Azores plume influence on the Mid-Atlantic Ridge north of the hotspot, Geology, 27, 991-994, 1999.

Grindlay, N. R., P. J. Fox, and K. C. Macdonald, Second-order ridge axis discontinuities in the South Atlantic: Morphology, structure and evolution, Mar: Geophys. Res., 13, 21-50, 1991.

Grindlay, N. R., J. A. Madsen, C. Rommevaux-Jestin, and J. Sclater, A different pattern of ridge segmentation and mantle Bouguer gravity anomalies along the ultra-slow spreading Southwest Indian Ridge, Earth Planet. Sci. Lett., 161, 243-253, 1998.

Hayes, D. E., Age-depth relationships and depth anomalies in the southeast Indian Ocean and South Atlantic Ocean, J. Geophys. Res., 93, $2937-$ 2954, 1988.

Hayes, D. E., and K. A. Kane, Long-lived mid-ocean ridge segmentation of the Pacific-Antarctic ridge and the Southeast Indian Ridge, J. Geophys. Res., 99, 19,679-19,692, 1994.

Hwang, C., E.-C. Kao, and B. Parsons, Global derivation of marine gravity anomalies from Seasat, Geosat, ERS-1 and TOPEX/POSEIDON altimeter data, Geophys. J. Int., 134, 449-459, 1998.

Jha, K., E. M. Parmentier, and J. Phipps Morgan, The role of mantledepletion and melt retention in spreading center segmentation, Earth Planet. Sc. Lett., 125, 221-234, 1994.

Kane, K. A., and D. E. Hayes, Tectonic corridors in the South Atlantic: Evidence for long-lived mid-ocean ridge segmentation, J. Geophys. Res., 97, 17,317-17,330, 1992.

Kane, K. A., and D. E. Hayes, Long-lived mid-ocean ridge segmentation: Constraints on models, J. Geophys. Res., 99, 19,693-19,706, 1994.

Keeton, J. A., R. C. Searle, B. Parsons, R. S. White, B. J. Murton, L. M. Parson, C. Pierce, and M. C. Sinha, Bathymetry of the Reykjanes Ridge, Mar. Geophys. Res., 19, 55-64, 1997.

Kincaid, C., D. W. Sparks, and R. Detrick, The relative importance of platedriven and buoyancy-driven flow at mid-ocean ridges, J. Geophys. Res., 101, 16,177-16,193, 1996

Kuo, B. Y., and D. W. Forsyth, Gravity anomalies of the ridge-transform system in the South Atlantic between $31^{\circ}$ and $34.5^{\circ} \mathrm{S}$ : Upwelling centers and variation in crustal thickness, Mar. Geophys. Res., 10, 205-232, 1988.

Lagabrielle, Y., D. Bideau, M. Cannat, J. A. Karson, and C. Mével, Ultramafic-mafic plutonic rock suites exposed along the Mid-Atlantic Ridge $\left(10^{\circ} \mathrm{N}-30^{\circ} \mathrm{N}\right)$. Symmetrical-asymmetrical distribution and implications for seafloor spreading processes, in Faulting and Magmatism at MidOcean Ridges, Geophys. Monogr. Ser., vol. 106, edited by W. R. Buck et al., pp. 153-176, AGU, Washington, D. C., 1998.

Laughton, A. S., R. C. Searle, and D. G. Roberts, The Reykjanes Ridge crest and the transition between its rifted and non-rifted regions, Tectonophysics, 55, 173-177, 1979.
Lin, J., G. M. Purdy, H. Schouten, J.-C. Sempéré, and C. Zervas, Evidence from gravity data for focused magmatic accretion along the Mid-Atlantic Ridge, Nature, 344, 627-632, 1990.

Ma, Y., and J. R. Cochran, Transitions in axial morphology along the Southeast Indian Ridge, J. Geophys. Res., 101, 15,849-15,866, 1996.

Macdonald, K. C., The crest of the Mid-Atlantic Ridge: Models for crustal generation processes and tectonics, in The Geology of North America, vol. M, The Western North Atlantic Region, edited by R. P. Vogt and B. E. Tucholke, pp. 51-68, Geol. Soc. of Am., Boulder, Colo., 1986.

Macdonald, K. C., D. S. Scheirer, and S. M. Carbotte, Mid-ocean ridges: Discontinuities, segments and giant cracks, Science, 253, 986-994, 1991.

Magde, L. S., D. W. Sparks, and R. S. Detrick, The relationship between buoyant mantle flow, melt migration, and gravity bull's eyes at the MidAtlantic Ridge between $33^{\circ} \mathrm{N}$ and $35^{\circ} \mathrm{N}$, Earth Planet. Sci. Lett., 148, $59-67,1997$.

Maia, M., and P. Gente, Three-dimensional gravity and bathymetry analysis of the Mid-Atlantic Ridge between $20^{\circ} \mathrm{N}$ and $24^{\circ} \mathrm{N}$ : Flow geometry and temporal evolution of the segmentation, J. Geophys. Res., 103, 951-974, 1998.

Marks, K. M., Resolution of the Scripps/NOAA marine gravity field from satellite altimetry, Geophys. Res. Lett., 23, 2069-2072, 1996.

Michael, P. J., et al., Mantle control of a dynamically evolving spreading center: Mid-Atlantic Ridge $31-34^{\circ} \mathrm{S}$, Earth Planet. Sci. Lett., 121, 451-468, 1994.

Müller, R. D., and W. R. Roest, Fracture zones in the North Atlantic from combined Geosat and Seasat data, J. Geophys. Res., 97, 3337-3350, 1992.

Müller, R. D., W. R. Roest, J.-Y. Royer, L. M. Gahagan, and J. G. Sclater, Digital isochrons of the world's ocean floor, J. Geophys. Res., 102, 3211-3214, 1997.

Müller, R. D., W. R. Roest, and J.-Y. Royer, Asymmetric sea-floor spreading caused by ridge-plume interactions, Nature, 396, 455-459, 1998.

Murton, B. J., and L. M. Parson, Segmentation, volcanism and deformation of oblique spreading centres: A quantitative study of the Reykjanes Ridge, Tectonophysics, 222, 237-257, 1993.

Mutter, J. C., and J. A. Karson, Structural processes at slow-spreading ridges, Science, 257, 627-634, 1992.

Neumann, G. A., and D. W. Forsyth, The paradox of the axial profile: Isostatic compensation along the axis of the Mid-Atlantic Ridge?, J. Geophys. Res., 98, 17,891-17,910, 1993.

Ondréas, H., D. Aslanian, L. Géli, J. L. Olivet, and A. Briais, Variations in axial morphology, segmentation and seafloor roughness along the Pacific-Antarctic Ridge between $56^{\circ} \mathrm{S}$ and $66^{\circ} \mathrm{S}$, J. Geophys. Res., 106, $8521-8546,2001$.

Palmer, J., J.-C. Sempéré, D. M. Christie, and J. Phipps-Morgan, Morphology and tectonics of the Australian-Antarctic Discordance between $123^{\circ} \mathrm{E}$ and $128^{\circ} \mathrm{E}$, Mar. Geophys. Res., 15, 121-152, 1993.

Pariso, J. E., J.-C. Sempéré, and C. Rommevaux, Temporal and spatial variations in crustal accretion along the Mid-Atlantic Ridge $\left(29^{\circ}-\right.$ $31^{\circ} 30^{\prime} \mathrm{N}$ ) over the last $10 \mathrm{Myr}$ : Implications from a three-dimensional gravity study, J. Geophys. Res., 100, 17,781-17,794, 1995.

Parmentier, E. M., and J. Phipps Morgan, Spreading rate dependence of three-dimensional structure in oceanic spreading centres, Nature, 348, $325-328,1990$

Parson, L. M., et al., En échelon axial volcanic ridges at the Reykjanes Ridge: A life cycle of volcanism and tectonics, Earth Planet. Sci. Lett., 117, 73-87, 1993.

Patriat, P., and J. Ségoufin, Reconstruction of the central Indian Ocean, Tectonophysics, 155, 211-234, 1988.

Phipps Morgan, J., and Y. J. Chen, Dependence of ridge-axis morphology on magma supply and spreading rate, Nature, 364, 706-708, 1993.

Phipps Morgan, J., and D. W. Forsyth, Three-dimensional flow and temperature perturbations due to a transform offset: Effects on oceanic crustal and upper mantle structure, J. Geophys. Res., 93, 2955-2966, 1988.

Phipps Morgan, J., and E. M. Parmentier, Crenulated seafloor: Evidence for spreading-rate dependent structure of mantle upwelling and melting beneath a mid-oceanic spreading center, Earth Planet. Sci. Lett., 129, 73-84, 1995.

Phipps Morgan, J., E. M. Parmentier, and J. Lin, Mechanisms for the origin of mid-ocean ridge axial topography: Implications for the thermal and mechanical structure of accreting plate boundaries, J. Geophys. Res., 92, 12,823-12,836, 1987.

Pokalny, R., P. Gente, and R. Buck, Oceanic transverse ridges: A flexural response to fracture-zone-normal extension, Geology, 24, 71-74, 1996.

Purdy, G. M., J.-C. Sempéré, H. Schouten, D. L. Dubois, and R. Goldsmith, Bathymetry of the Mid-Atlantic Ridge, $24^{\circ}-31^{\circ} \mathrm{N}$ : A map series, Mar. Geophys. Res., 12, 247-252, 1990.

Rabinowicz, M., and A. Briais, Temporal variations of the segmentation of slow to intermediate spreading mid-ocean ridges, 2 , A three-dimensional 
model in terms of lithosphere accretion and convection within the partially molten mantle beneath the ridge axis, J. Geophys. Res., 10.1029/ 2001JB000343, in press, 2002

Rabinowicz, M., S. Rouzo, J.-C. Sempéré, and C. Rosemberg, Threedimensional mantle flow beneath mid-ocean ridges, J. Geophys. Res., 98, 7851-7869, 1993

Rommevaux, C., C. Deplus, P. Patriat, and J.-C. Sempéré, Three-dimensional gravity study of the Mid-Atlantic ridge: Evolution of the segmentation between $28^{\circ}$ and $29^{\circ} \mathrm{N}$ during the last $10 \mathrm{Myr}$, J. Geophys. Res., 99, 3015-3029, 1994.

Rommevaux-Jestin, C., C. Deplus, and P. Patriat, Mantle Bouguer anomaly along an ultra slow-spreading ridge: Implications for accretionary processes and comparison with results from central Mid-Atlantic Ridge, Mar. Geophys. Res., 19, 481-503, 1997.

Rouzo, S., M. Rabinowicz, and A. Briais, Segmentation of mid-ocean ridges with an axial valley induced by small-scale convection, Nature, 374, 795-798, 1995.

Sahabi, M., L. Géli, J.-L. Olivet, L. Gilg-Capar, G. Roult, H. Ondréas, P. Beuzart, and D. Aslanian, Morphological reorganization within the Pacific-Antarctic discordance, Earth Planet. Sci. Lett., 137, 157-173, 1996.

Sandwell, D. T., Thermomechanical evolution of oceanic fracture zones, J. Geophys. Res., 89, 11,401-11,413, 1984.

Sandwell, D. T., and W. H. F. Smith, Marine gravity anomaly from Geosat and ERS 1 satellite altimetry, J. Geophys. Res., 102, 10,039-10,054, 1997.

Scheirer, D. S., and K. C. Macdonald, Near-axis seamounts on the flanks of the East Pacific Rise, $8^{\circ} \mathrm{N}$ to $17^{\circ} \mathrm{N}$, J. Geophys. Res., 100, 2239-2259, 1995

Scheirer, D. S., K. C. Macdonald, D. W. Forsyth, and Y. Shen, Abundant seamounts of the Rano Rahi seamount field near the southern East Pacific Rise, $15^{\circ} \mathrm{S}$ to $19^{\circ} \mathrm{S}$, Mar. Geophys. Res., 18, 13-52, 1996.

Scheirer, D. S., D. W. Forsyth, J. A. Conder, M. A. Eberle, S.-H. Hung, K. T. M. Johnson, and D. W. Graham, Anomalous seafloor spreading of the Southeast Indian Ridge near the Amsterdam-St. Paul Plateau, J. Geophys. Res., 105, 8243-8262, 2000.

Schouten, H., K. D. Klitgord, and J. A. Whitehead, Segmentation of midocean ridges, Nature, 317, 225-229, 1985.

Schouten, H., H. J. B. Dick, and K. D. Klitgord, Migration of mid-oceanridge volcanic segments, Nature, 326, 835-839, 1987.

Scott, D. R., and D. J. Stevenson, A self-consistent model of melting, magma migration and buoyancy-driven circulation beneath mid-ocean ridges, J. Geophys. Res., 94, 2973-2988, 1989.

Searle, R. C., J. A. Keeton, R. B. Owens, R. S. White, R. Mecklenburgh, B. Parsons, and S. M. Lee, The Reykjanes Ridge: Structure and tectonics of a hot-spot-influenced, slow-spreading ridge, from multibeam bathymetry, gravity and magnetic investigations, Earth Planet. Sci. Lett., 160, 463-478, 1998

Sempéré, J.-C., J. Palmer, D. Christie, J. Phipps Morgan, and A. Shor, The Australian-Antarctic Discordance, Geology, 19, 429-432, 1991.

Sempéré, J.-C., J. Lin, H. S. Brown, H. Schouten, and G. M. Purdy, Segmentation and morphotectonic variations along a slow-spreading center: The Mid-Atlantic Ridge $\left(24^{\circ} 00^{\prime} \mathrm{N}-30^{\circ} 40^{\prime} \mathrm{N}\right)$, Mar. Geophys. Res., 15, 153-200, 1993.

Sempéré, J. C., P. Blondel, A. Briais, T. Fujiwara, L. Géli, N. Isezaki, J. E. Pariso, L. M. Parson, P. Patriat, and C. Rommevaux, The Mid-Atlantic Ridge between $29^{\circ} \mathrm{N}$ and $31^{\circ} 31^{\prime} \mathrm{N}$ in the last $10 \mathrm{Ma}$, Earth Planet. Sci. Lett., 130, 45-55, 1995.

Sempéré, J. C., B. P. West, and L. Géli, The Southeast Indian Ridge between $127^{\circ}$ and $132^{\circ} 40^{\prime} \mathrm{E}$ : contrasts in segmentation characteristics and implications for crustal accretion, in Tectonic, Magmatic, Hydrothermal and Biological Segmentation of Mid-Ocean Ridges, edited by C. J. MacLeod, P. A. Tyler, and C. L. Walker, Geol. Soc. Spec. Publ., 118, 1-15, 1996.

Shah, A. K., and J.-C. Sempéré, Morphology of the transition from an axial high to rift valley at the Southeast Indian Ridge and the relation to variations in mantle temperature, J. Geophys. Res., 103, 5203-5223, 1998.

Shaw, P. R., and S. C. Cande, High-resolution inversion for South Atlantic plate kinematics using joint altimeter and magnetic anomaly data, J Geophys. Res., 95, 2625-2644, 1990

Shaw, W. J., and J. Lin, Models of ocean ridge lithospheric deformation: Dependence on crustal thickness, spreading rate, and segmentation, J Geophys. Res., 101, 17,977-17,993, 1996.

Sloan, H., and P. Patriat, Kinematics of the North American-African plate boundary between $28^{\circ}$ and $29^{\circ}$ during the last $10 \mathrm{Ma}$ : Evolution of the axial geometry and spreading rate, Earth Planet. Sci. Lett., 113, 323-341, 1992.

Small, C., Observations of ridge-hotspot interactions in the Southern Ocean, J. Geophys. Res., 100, 17,931-17,946, 1995.

Small, C., and D. T. Sandwell, An analysis of ridge axis gravity roughness and spreading rate, J. Geophys. Res., 97, 3235-3245, 1992.

Sparks, D. W., E. M. Parmentier, and J. Phipps Morgan, Three-dimensional mantle convection beneath a segmented spreading center: Implications for along-axis variations in crustal thickness and gravity, J. Geophys. Res., 98, 21,977-21,996, 1993.

Talwani, M., C. C. Windisch, and M. G. Langseth Jr., Reykjanes Ridge crest: A detailed geophysical study, J. Geophys. Res., 76, 473-517, 1971.

Thibaud, R., P. Gente, and M. Maia, A systematic analysis of the MidAtlantic Ridge morphology and gravity between $15^{\circ} \mathrm{N}$ and $40^{\circ} \mathrm{N}$ : Constraints of the thermal structure, J. Geophys. Res., 103, 24,223-24,243, 1998.

Tolstoy, M., A. J. Harding, and J. A. Orcutt, Crustal thickness on the MidAtlantic Ridge: Bull's eye gravity anomalies and focused accretion, Science, 262, 726-729, 1993

Tucholke, B. E., J. Lin, M. C. Kleinrock, M. A. Tivey, T. B. Reed, J. Goff, and G. E. Jaroslow, Segmentation and crustal structure of the western Mid-Atlantic Ridge flank, $25^{\circ} 25^{\prime}-27^{\circ} 10^{\prime} \mathrm{N}$ and $0-29 \mathrm{Myr}, J$. Geophys. Res., 102, 10,203-10,223, 1997.

Vogt, P. R., Asthenosphere motion recorded by the ocean floor south of Iceland, Earth Planet. Sci. Lett., 13, 153-160, 1971.

Vogt, P. R., N. A. Ostenso, and G. L. Johnson, Magnetic and bathymetric data bearing on seafloor spreading north of Iceland, J. Geophys. Res., 75, 903-921, 1970 .

Weissel, J. K, and D. E. Hayes, The Australian-Antarctic Discordance: New results and implications, J. Geophys. Res., 79, 2579-2587, 1974.

West, B. P., J.-C. Sempéré, D. G. Pyle, J. Phipps Morgan, and D. M. Christie, Evidence for variable upper mantle temperature and crustal thickness in and near the Australian-Antarctic Discordance, Earth Planet. Sci. Lett., 128, 135-153, 1994.

West, B. P., W. S. D. Wilcock, J.-C. Sempéré, and L. Géli, Three-dimensional structure of asthenospheric flow beneath the Southeast Indian Ridge, J. Geophys. Res., 102, 7783-7802, 1997.

West, B. P., J. Lin, and D. M. Christie, Forces driving ridge propagation, J. Geophys. Res., 104, 22,845-22,858, 1999

White, R. S., J. W. Bown, and J. R. Smallwood, The temperature of the Iceland plume and origin of outward-propagating $\mathrm{V}$-shaped ridges, J. Geol. Soc. London, 152, 1039-1045, 1995.

Whitehead, J. A., H. J. B. Dick, and H. Schouten, A mechanism for magmatic accretion under spreading centres, Nature, 312, 146-148, 1985 .

Wolfe, C. J., G. M. Purdy, D. R. Toomey, and S. C. Solomon, Microearthquake characteristics and crustal velocity structure at $29^{\circ} \mathrm{N}$ on the MidAtlantic Ridge: The architecture of a slow spreading segment, J. Geophys. Res., 100, 24,449-24,472, 1995.

A. Briais, Laboratoire d'Etudes en Géophysique et Océanographie Spatiales, CNRS, UMR 5566, Observatoire Midi-Pyrénées, 14, Avenue Edouard Belin, F-31400 Toulouse, France. (Anne.Briais@cnes.fr)

M. Rabinowicz, Laboratoire de Dynamique Terrestre et Planétaire, UMR 5562, Observatoire Midi-Pyrénées, 14, Avenue Edouard Belin, F-31400 Toulouse, France. (Michel.Rabinowicz@cnes.fr) 

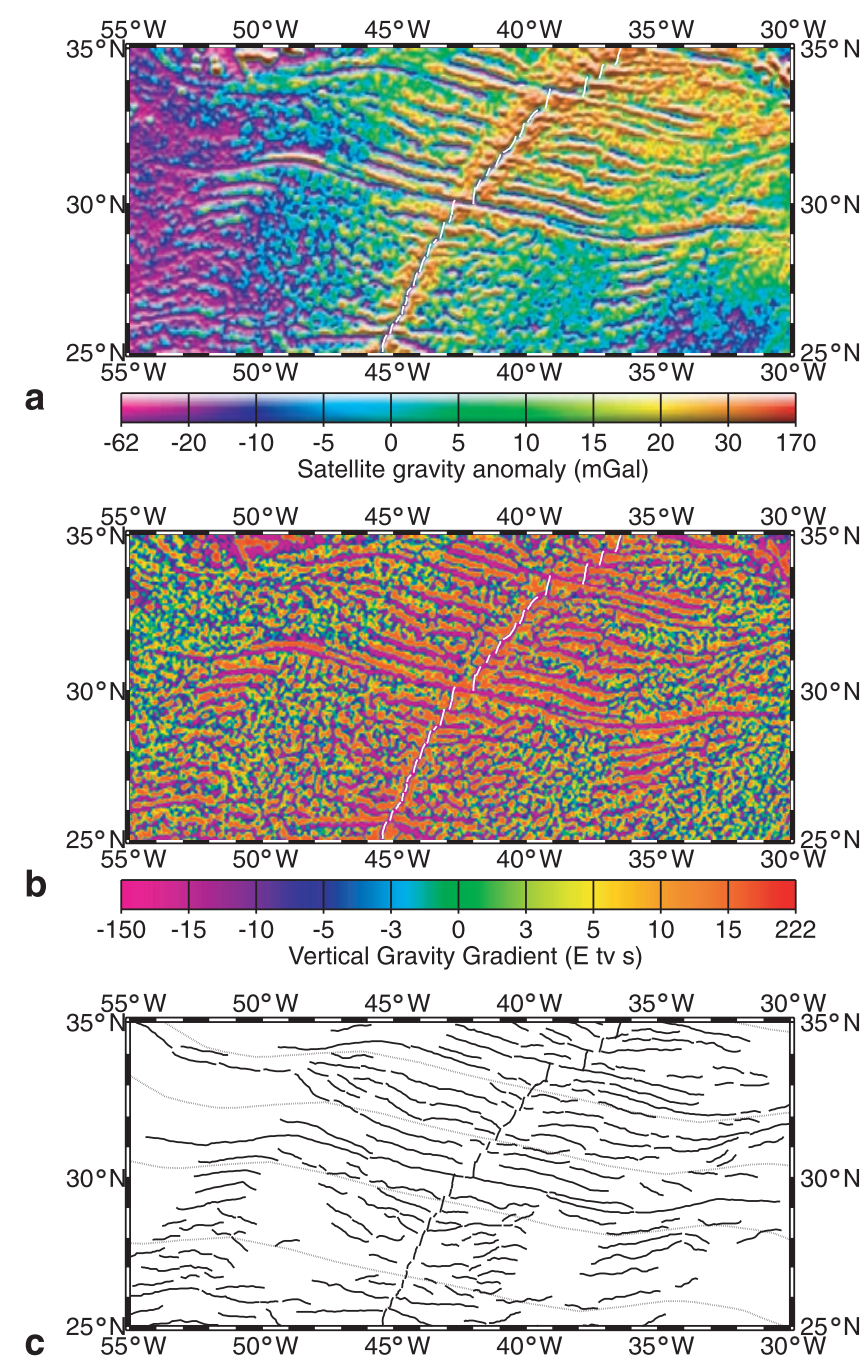

Figure 1. (a) Shaded relief map of the free-air gravity anomalies in the central Atlantic [Sandwell and Smith, 1997]. (b) Vertical gravity gradient in the same area as Figure 1a (W. H. F. Smith, written communication, 1999) (c) Discontinuity traces identified from Figures $1 \mathrm{a}$ and $1 \mathrm{~b}$ shown as thin solid lines. Thick lines are mid-ocean ridge axis. Dotted lines are flow lines drawn using Müller et al.'s [1997] finite poles of rotation. 

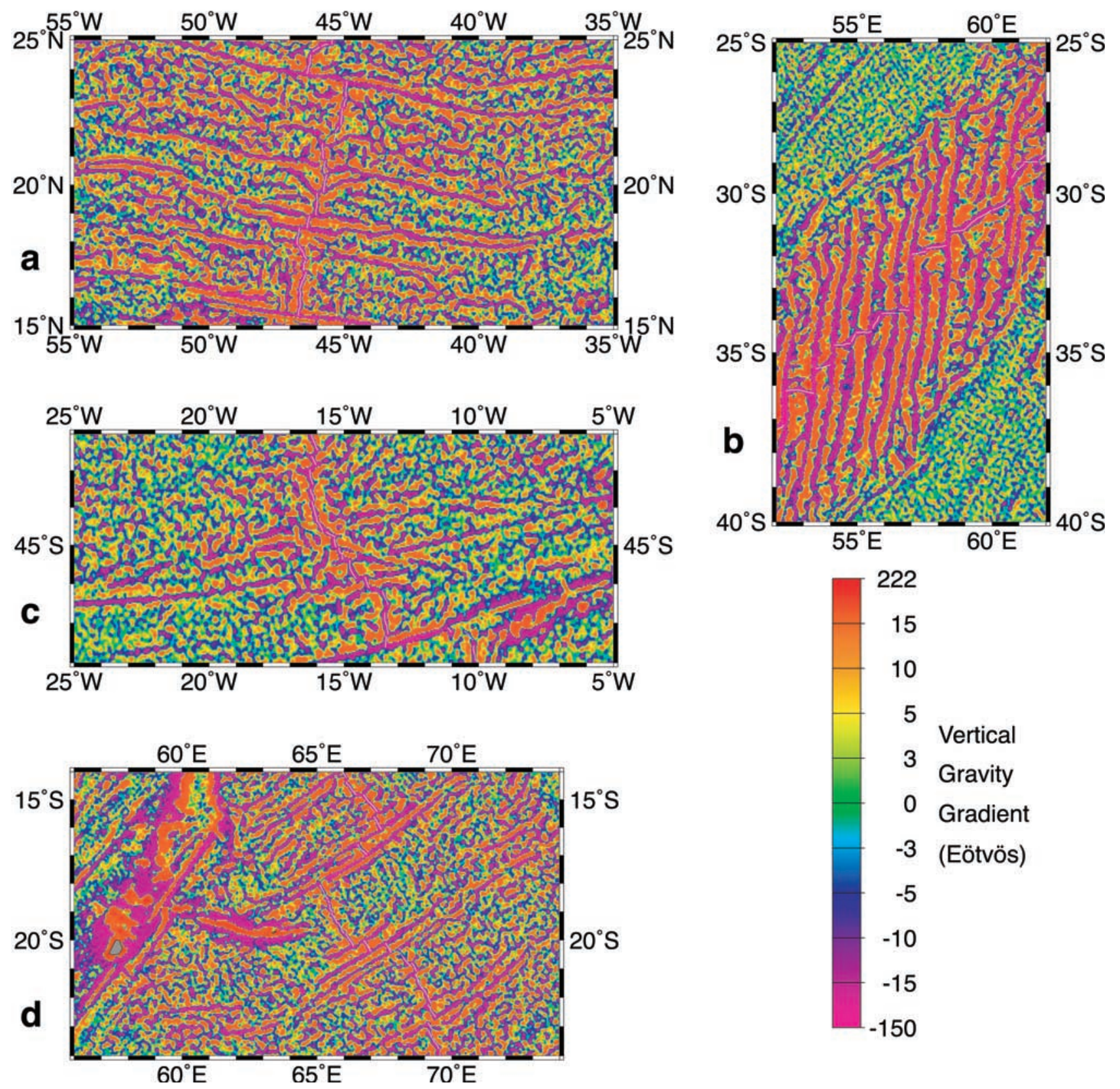

Figure 11. Maps of the vertical gravity gradient in areas typical of the segmentation evolution. (a) Kane to $15^{\circ} 20^{\prime} \mathrm{N}$ section of the MAR. (b) Gallieni to Melville TF section of the SWIR. (c) Southern Mid-Atlantic Ridge affected by hot spots. (d) Marie Celeste to Egeria section of the CIR. 